\title{
Migrating, Morphing, and Vanishing: The Empirical and Normative Puzzles of Declining Trial Rates in Courts
}

\author{
Judith Resnik*
}

This article explores competing explanations of the data on declining rates of trials in the federal courts of the United States. One possibility is that while trials have declined in courts, trials have migrated elsewhere, resulting in a proliferation of adjudicatory processes. The proliferation thesis has plausibility because of the positive political significance now attached to trials and the adjudicatory processes for which they stand. Conversely, a second analysis of the data focuses instead on the rarity of trials in courts and the negative rhetoric and rules stemming from courts about trials. The data could mark the privatization of disputing processes, whether located in or out of courts. The available data also reveal the political and economic incentives and capabilities of the legal profession. The gaps in data on adjudication in state courts and within agencies reflect the lower priority paid to those kinds of claims. The disparity between the federal system and the others (which provide adjudicatory mechanisms for most complainants in the United States) illustrates the impoverishment of public provisions for dispute resolution. History, law, and tradition also support public access to courts, making them more transparent than more recently invented decision-making centers. But one should not assume the stability of either the equation of courts with public access or the equation of administrative agen-

\footnotetext{
*Arthur Liman Professor of Law, Yale Law School, 127 Wall St., New Haven, CT 06511; e-mail judith.resnik@yale.edu.

This article was written for the American Bar Association Symposium, "The Vanishing Trial," held in San Francisco in December 2003. My thanks to Marc Galanter and to Stephan Landsman who convened us and who peppered us with data; to Andrew Goldstein, Kate Andrias, Heather Lewis, Alison Mackenzie, Jennifer Peresie, and Bertrall Ross, who have taught me a lot about contemporary procedural opportunities; to Rebecca Wexler for able help in production; and to Dennis Curtis, Owen Fiss, John Langbein, Michael Asimow, Jerry Mashaw, Vicki Jackson, Deborah Hensler, Louise LaMothe, and Tony Klein, with whom I continue to learn about the possibilities of process.

This article builds on other work, specifically the chapter Civil Processes in The Oxford Handbook of Legal Studies (Peter Cane \& Mark Tushnet eds., 2003); and the articles Trial as Error, Jurisdiction as Injury: Transforming the Meaning of Article III, 113 Harv. L. Rev. 925 (2000); Due Process: A Public Dimension, 39 U. Fla. L. Rev. 405 (1987); and For Owen M. Fiss: Some Reflections on the Triumph and Death of Adjudication, 58 U. Miami L. Rev. 173 (2003).
} 
cies and private providers with secrecy. Courts' processes are increasingly private, prompting the question of whether to insist (as some judges and state legislators now do) on public access to information about outcomes (settlements included) that are generated through courts, or to permit invisible and sometimes secret resolutions. Whether trials are migrating, morphing, or vanishing, the normative questions now pending are whether a role ought to be preserved for public participation in dispute resolution in either courts or their alternatives and how public resources will be distributed to support either sector.

\section{Contracting For the (VANishing) Trial}

In late October 2003, I received a contract from the American Bar Association (ABA). The contract, which embodies the agreement to write this article, has several terms. Included is the provision that if a dispute were to arise, the laws of the State of Illinois would govern and, further, that "any actions brought hereunder will only be brought in state or federal courts of competent jurisdiction located in Chicago, Illinois."

This contract differs significantly from many others that I have reviewed in the last few years-sent to me by my cell phone carrier, my computer's manufacturer, my new car's manufacturer, and by accountants working for a board on which I serve. In these other contracts, clauses like the one below (under the heading "Independent Arbitration") appear.

Instead of suing in court, you're agreeing to arbitrate disputes arising out of or related to this or prior agreements... You and we are waiving rights to participate in class actions, including putative class actions begun by others prior to this agreement ...."2

\footnotetext{
'Section 8.05 of the Contract for Services, attached to letter of October 22, 2003 from Professor Stephan Landsman to this author. On file with the author. Participants were asked to write articles related to data disseminated in October 2003 by Professor Marc Galanter. See The Vanishing Trial: An Examination of Trials and Related Matters in Federal and State Courts, compiled by Marc Galanter for the Symposium on The Vanishing Trial, sponsored by the Litigation Section of the American Bar Association, Dec. 12-14, 2003 [hereinafter Galanter, Vanishing Trial 2003 Version].

2This text comes from a mailing I received in 2002 from Verizon Wireless, which also counseled that I read [it] carefully before filing [it] in a safe place." On file with the author. See also Linda J. Demaine \& Deborah R. Hensler, "Volunteering" to Arbitrate Through Predispute Arbitration Clauses: The Average Consumer's Experience, 67 L. \& Contemp. Probs. 55 (2004). The authors sampled consumer services, such as moving companies, department stores, car dealers, hospitals, airlines, and credit card dealers and learned that about one-third ( 57 of the 161 sampled businesses) included arbitration clauses in their contracts. Almost 70 percent of financial services (credit cards, accounting, banking) required arbitration. Of the 52 arbitration clauses analyzed, about one-third expressly prohibited class actions. Of 28 clauses that dealt with costs, about half provided that the consumer and service company would split the costs, unless the arbitrator decided otherwise.
} 
In contrast, the $\mathrm{ABA}$ has not required as a condition of agreement that I waive my right to trial and go through a dispute resolution system provided by the contract's drafter.

The ABA contract provides evidence that the leaders of the ABA still believe in the possibility of having a trial and retain a normative commitment to preserving the opportunity for people in conflict to turn to courts. ${ }^{3}$ But the Symposium-"The Vanishing Trial"-for which the contract was written is itself premised on evidence of a different kind. The data assembled by the research team led by Marc Galanter document that not everyone shares the ABA's willingness to leave open a courthouse door.

In this article, I explore competing explanations of the data on declining rates of trials in courts. One possibility is that while trials have declined in courts, trials have in fact migrated elsewhere, resulting in a proliferation of adjudicatory processes. The data requisite to substantiate this theory are missing because, as I detail below, the major institutions of the bench and bar are "court-centric," devoting resources to gathering information about state and federal courts but not about the other public courts in our system, based in agencies, nor about privately provided dispute centers.

The proliferation thesis has plausibility because of the positive political significance now attached to trials and the adjudicatory processes for which they stand. Democracy has come to be understood as predicated on obligations by governments to give individuals the opportunity to enforce rights against the state, to respect the human rights of individuals, and to provide access to information about the exercise of power by both public and private actors. The empirical bases supporting this normative assessment come from national and transnational agreements evidencing a worldwide political consensus that transparent adjudicatory processes are a prerequisite to successful market-based democracies.

Conversely, another analysis of the data focuses instead on the rarity of trials in courts and the negative rhetoric and rules stemming from courts about trials. This argument relies on a host of rules, statutes, doctrines, and practices urging or insisting that disputants have limited access to the most high-profile courts (the federal courts) in the United States and must find means other than adjudication to respond to conflict. Together, those data mark a different normative consensus-one that rejects the public adjudicatory model. Yet the groups skeptical or hostile to trials do not all have the same complaints. Some are critical because they see trials as unresponsive to personal needs. Others object to lawyer dominance and profiteering. Yet others seek to constrain the power and reach of government by limiting adjudication's role in generating and imposing public norms. Such critics have forged poli-

${ }^{3} 1$ prefer this reading to a less cheerful one, that the ABA knows the data on trials and comfortably offers that option because of the low likelihood of its use. 
cies that devalue the use of public trials for dispute resolution. The data, under this reading, tell us that we are watching the privatization of disputing processes, whether located in or out of courts.

My view is that these seemingly divergent explanations are both fair readings of the vast quantum of relevant information. They diverge by focusing on different aspects of events within and beyond the United States. Moreover, these two analyses share a common core. Both are premised on the fact that, during the 20th century, the prospect of adjudication became plausible for whole new sets of claimants as different political conceptions of people, governments, and markets became dominant.

Four central changes occurring during the 20th century need to be highlighted. First, governments recognized greater obligations to subject themselves to regulation, to be bound by their own rules, and to treat persons with dignity and respect. Individuals gained the right to use litigation to call state officials to account and to hold government to its own promises. ${ }^{4}$ Sometimes, the examples include dramatic pronouncements of human rights but, more frequently, examples come from less vivid events, such as rights to fair treatment in administrative decision making. Second, in part through new information technologies, injuries experienced by large numbers of individuals that were once seen as individualized and isolated occurrences became visible as patterns of connected events. Mechanisms to aggregate claims and parties followed. Third, the growth of the profession of lawyers provided the personnel to generate regulations and responses to both individual and aggregate forms of injury. ${ }^{5} \mathrm{~A}$ fourth factor, one that has been underappreciated in the literature of courts, is women's rights. Women gained juridical voice only in the last century, and the radical reconception of women as rightsholders ${ }^{6}-$ both inside and outside of their families-has driven up the volume of disputes. ${ }^{7}$

\footnotetext{
${ }^{4}$ See generally, Vicki C. Jackson, Suing the Federal Government: Sovereignty, Immunity, and Judicial Independence, 35 Geo. Wash. Int'l L. Rev. 521 (2003); James E. Pfander, Government Accountability in Europe: A Comparative Assessment, 35 Geo. Wash. Int'1 L. Rev. 611 (2003); Judith Resnik \& Julie Chi-hye Suk, Adding Insult to Injury: Questioning the Role of Dignity in Conceptions of Sovereignty, 55 Stan. L. Rev. 1951 (2003) [hereinafter Resnik \& Suk, Dignity and Sovereignty].
}

${ }^{5}$ See, e.g., Richard L. Abel \& Phillip S.C. Lewis, Lawyers in Society: An Overview (1995); Stephen C. Yeazell, Re-Financing Civil Litigation, 51 DePaul L. Rev. 183 (2001).

'See, e.g., Judith Resnik: Reconstructing Equality: Of Justice, Justicia, and the Gender of Jurisdiction, 14 Yale J. L. \& Feminism 393 (2002); Reva B. Siegel, She the People: The Nineteenth Amendment, Sex Equality, Federalism, and the Family, 115 Harv. L. Rev. 947 (2002); Rosa Ehrenreich Brooks, Feminism and International Law: An Opportunity for Transformation, 14 Yale J. L. \& Feminism 345 (2002); Vicki C. Jackson, Gender and Transnational Legal Discourse, 14 Yale J. L. \& Feminism 377 (2002).

${ }^{7}$ One illustration from outside the United States is that the highest demand on civil legal aid funds in England has come from disputes categorized as family conflicts. See Tamara Goriely, Making the Welfare State Work: Changing Conceptions of Legal Remedies Within the British Welfare State, in The Transformation of Legal 
Women's rights exemplify a more general understanding that all persons, whatever their colors, ages, religions, nationalities, ethnicities, and races, can bring claims of legal right.

Adjudication's simultaneous proliferation and devaluation are interrelated and interdependent outcomes of these developments. For narrative clarity, I will abstract one from the other as I shape the argument for each below. The existence of competing assessments, in turn, prompts questions about the relative strengths of constituencies for adjudication and for privatization. As I will argue, the data gaps (which limit our ability to assess whether trials have migrated and morphed rather than vanished) are themselves windows into the incentives and agendas of the leadership of the legal profession, which in turn will play a significant role in determining which of these competing trends is to dominate in the years to come.

The information provided (as well as that missing) makes plain that the history and tradition of courts as publicly accessible institutions enables obtaining knowledge about their processes more easily than those of the recently invented "courts" in agencies and arbitration centers. Yet, this public dimension of courts is at risk. As I detail, courts' practices and processes are increasingly private, prompting the question of whether to insist, as some state legislatures are now doing, on public access to information about outcomes in certain kinds of disputes.

Further, the data demonstrate the success of last century's legal reformers who enabled the federal courts to become such a rich judicial system. The budget allocations, described below, permit us to know much more about the federal courts (which process a small fraction of the nation's legal claims) than we do about state courts or agency adjudication or private processes. If resources in the federal system provide an appropriate benchmark for a reasonably supported public system, then the disparity between the federal system and all others establishes that adjudicatory mechanisms for most complainants in the United States are deeply impoverished.

It is not news that more funds are needed for adjudicatory processes. But a question remains about how funds have been generated for one segment of the adjudicatory spectrum and much less for others. What explains the current allocations? As proponents of adjudication multiplied courts and proliferated adjudication in agencies, they also elaborated hierarchies of judges, cases, and litigants. Both highend and low-end disputants have been able to attract attention from the legal establishment, which helped certain kinds of cases (including civil rights, environmental

Aid: Comparative and Historical Studies 89, 108 (Francis Regan, Alan Paterson, Tamara Goriely \& Don Fleming eds., 1999). Data from inside the United States demonstrate that this arena of life also creates a higher density of disputes than do other arenas. See David M. Trubek, Austin Sarat, William L.F. Felstiner, Herbert M. Kritzer \& Joel B. Grossman, The Costs of Ordinary Litigation, 31 UCLA L. Rev. 72, 87, tbl. I (Litigation as a Percentage of Disputes). 
claims, commercial litigation, federal statutory rights involving economically substantial claims, as well as some criminal prosecutions) become inscribed as nationally important. ${ }^{8}$ Funding and attention were both predicates to and outcomes of the federal court system's dominance.

Many other disputants (from consumers with computers at risk of crashing, to workers injured on the job, to the disabled and veterans contesting benefits, to immigrants worried about their status, to women seeking support for their children or protection from household violence) have sought entry to Article III courts. Through lawyer-assisted political action, certain sets of claimants (e.g., victims of domestic violence) have been able to obtain access to some process-based redress. Further, for some, class actions serve as a vehicle for pursuing legal rights, but that avenue has been narrowed and, as noted above, is sometimes precluded through contract. ${ }^{9}$ Thus, for many others (such as low-end consumers and workers), law-based remedies remain largely unattainable. ${ }^{10}$ Moreover, in the battles over access, the leadership of the federal judiciary has used its own data-collection capacities to argue against legislation that would admit new sets of litigants into its halls. ${ }^{11}$

I do not believe that the federal courts need or should be either the only or the preferred avenue for redress. Rather, on the federal side, the many agency-courts (about which we know too little) can be excellent venues for decision making (including for trials). But, despite some efforts, neither bar leaders, jurists, nor academics have been able to bring into view and obtain sustaining support for agencybased courts. Moreover, judges within agencies are specially vulnerable, as agencies try to shift adjudication from administrative law judges who have some independence through statutory protections to line employees. The focus on the federal courts

\footnotetext{
${ }^{8}$ For discussion of the equation of "the federal" with the "important" and then how certain cases came to be understood as "a federal case" and others seen as inappropriate for federal adjudication, see Judith Resnik, Trial as Error, Jurisdiction as Injury: Transforming the Meaning of Article III, 113 Harv. L. Rev. 924, 967-83 (2000) [hereinafter Resnik, Trial as Error].
}

9See generally, Deborah R. Hensler, Bonnie Dombey-Moore, Elizabeth Giddens, Jennifer Gross, Erik K. Moller \& Nicholas M. Pace, Class Action Dilemmas: Pursuing Public Goals for Private Gain (RAND, 2000); Jean R. Sternlight \& Elizabeth J. Jensen, Using Arbitration to Eliminate Class Actions: Efficient Business Practice or Unconscionable Abuse?, 67 Law \& Contemp. Probs. 75 (2004). On the rise of class actions to enable access and the controversy thus engendered, see Judith Resnik, From "Cases" to "Litigation," 54 Law \& Contemp. Probs. 5 (1991). Proposals to impose new limitations on class actions can be found in The Class Action Fairness Act of 2003, S. 1751, discussed in 4 Class Action Litigation Report 930 (Dec. 26, 2003).

${ }^{10}$ The problem of no access to process is true both in and outside of the United States. See Hazel Genn, Paths to Justice: What People Do and Think about Going to Law (Oxford, 1999).

${ }^{11}$ See Resnik, Trial as Error, supra note 8, at 968-83; Judith Resnik, Constricting Remedies: The Rehnquist Judiciary, Congress, and Federal Power, 78 Ind. L.J. 223, 272-91 (2003) [hereinafter Resnik, Constricting Remedies]. 
has come without (or at the expense of) comparable attention paid to the other venues of adjudication. Given that the current holders of political power in the federal government number among the proponents of devaluing trials and privatizing processes, supporters of the public dimensions of trials and adjudication in the United States will have to reevaluate their own work-if they want independent adjudicatory processes to endure.

As I discuss below, the federal judiciary has in recent decades been in the forefront of the anti-adjudication movement. But the leadership of the federal courts may need to reassess the wisdom of its position. The federal courts gained a central place in this Symposium's data on "The Vanishing Trial" by virtue of a political and social order committed to court-based processing that vested so much power in and sent so many cases to the federal judiciary. As adjudication is eclipsed by the very alternatives that federal judges have promoted and (through both rule making and adjudication) mandated, the need to support federal courts diminishes. The declining number of trials could portend a declining level of funding, a concern one can find within the pages of the reports of the Administrative Office (AO) of the U.S. Courts. The AO has begun to takes pains to explain in its annual statistical reports that, despite the absence of trials, judges need courtrooms in which to do their work and, moreover, that federal judges remain very busy.

Yet the ongoing difficulty in persuading Congress to raise federal judges' salaries $^{12}$ and current concerns about funding of court processes themselves ${ }^{13}$ suggest that more than federal judges and ABA affiliates are needed as constituencies to press Congress for its support of courts. If proponents of the federal courts broaden their focus to argue for resources for an adjudicatory system beyond the walls of those buildings, they may be able to shape a political understanding (and then budgets) for state and federal courts and agency-based adjudication. In sum, were one to want to reverse the trends toward privatization, the decline of trials in courts, and the hostile rhetoric toward trials, one would have to reorient the bench and bar to create a political demand to augment and to redistribute judicial resources. If not, trials may well vanish-in courts, agencies, and beyond.

\footnotetext{
12The American Bar Association has been a long-time supporter of better pay for judges. Its efforts were renewed in 2003. See American Bar. Ass'n Standing Comm. on Fed. Judicial Improvements, Report to the House of Delegates (2003) (citing the National Commission on the Public Service, chaired by Paul Volcker, and urging Congress to adopt "an immediate and significant increase" in judicial pay), available at <http://www.abanet.org/scfji/pdf.volkerrecrep.pdf>; and Federal Judicial Pay: An Update on the Urgent Need for Action (ABA, Federal Bar Association, May 2003), available at <http://www.abanet.org/ poladv/2003judpay.html.
}

${ }^{13}$ See Katerina M. Eftimoff, Staffing Cuts Expected in Federal Courts, 29 ABA Litig. News 1 (May 2004) (describing congressional appropriations that were $\$ 267.2$ million less than required). 


\section{MIGRATION AND REPLACEMENT?}

\section{A. Definitional and Empirical Questions}

A first empirical challenge is what to make of the fact that trials are now an oddity in courts. ${ }^{14}$ As I detail below, it is plausible to argue that trials have migrated (or been exiled) to other places, including to other rooms inside courts, to administrative agencies, and to private office buildings. Under this approach, courts-not trialsare atrophying. ${ }^{15}$

\section{1. "Looking for Data"16}

Marc Galanter has (as always) made an impressive foray into data collection about trials. But at the time when materials were distributed to those writing papers, the sections "Administrative Adjudication"17 and "The Number of ADR Proceedings"18 had not been written. Rather, they were delineated by brackets and comments such as "Other figures"19 or "this section to be developed. Looking for data . . ."20 As Professor Galanter properly noted, such data are in fact "elusive."

${ }^{16}$ Galanter, Vanishing Trial 2003 Version, supra note 1 , at 90 .
${ }^{17}$ Id. at 62.
${ }^{18}$ Id. at 90.
${ }^{19}$ Id. at 62.
${ }^{20}$ Id. at 90.
${ }^{21}$ Id. at 91. 
On the private side, the market is comprised of many different providers, some free-standing institutions and others in-house programs. On the public side, the hundreds of agencies that are functionally courts in the federal and state systems do not pool data and (like courts) have differing methods of recording what comes before them and how filings are resolved. Thus, data needed to substantiate the proliferation thesis are missing. Specifically, we know less about adjudicatory processes in agencies than in courts. Moreover, the very capacity to gather data on courts and the absence of comparable information on other venues prompts other inquiries. How did the infrastructure that has produced the data we do have come to be, and what accounts for the disparity of knowledge about proceedings in and outside of courts? What can we learn about declining trial rates by mining the data-gathering processes themselves?

\section{The Political Economies of Data Production on Disputes}

The brief answer is that we are the beneficiaries of prior generations of institutional reformers, who-with imagination, political commitment, and clout-created institutions such as the ABA, the American Law Institute (ALI), the Judicial Conference of the United States with its Administrative Office (AO) and Federal Judicial Center (FJC), the National Center for State Courts (NCSC), and the National Conference of Commissioners on Uniform State Laws (NCCUSL). These entities, supported by the private sector, foundations, and/or government funds, have flourished-producing laws, processes, and data. In contrast, other segments of the adjudication system, most notably state and federal agencies, lack the resources (in terms of funds and political capital) to obtain the means by which to illuminate their own functions.

a. Gaining the Capacity to Count Cases in Courts. To appreciate the wealth of courtcentered data, we need to remember the lack of any means to gather such information only 100 years ago, when the 100-plus federal trial judges were a group who, as William Howard Taft put it, each "paddled his own canoe." ${ }^{22}$ During the first half of the 20th century, law reformers changed that isolation by producing many of the legal institutions that I listed above. Impressive successes in Congress and in the private sector have created entities serving major national interests and constituencies. ${ }^{23}$

Victories include the establishment of the Judicial Conference of the United States (in 1922), the Administrative Office of the U.S. Courts (in 1939), and the Federal Judicial Center (in 1967), as well as authorizations from Congress of hun-

\footnotetext{
${ }^{22}$ William Howard Taft, The Possible and Needed Reforms in Administration of Justice in the Federal Courts, 8 A.B.A. J. 601,602 (1922).

${ }^{23}$ See generally, Robert W. Gordon, The Legal Profession, in Looking Back at Law's Century 287-336 (Austin Sarat, Bryant Garth \& Robert A. Kagan eds., 2002).
} 
dreds of new life-tenured judgeships, development of the magistrate and bankruptcy judges systems (in 1968 and in 1984), ${ }^{24}$ expansion of the federal judicial administrative apparatus, and budgetary growth from 57 million dollars in 1962 to 4.823 billion dollars in $2002 .{ }^{25}$ The federal judiciary has gained the resources to study itself, to produce a monthly newsletter (The Third Branch, begun in 1968), ${ }^{26}$ and to construct (through an innovative public/private agreement) the Thurgood Marshall Building (opened in 1992). ${ }^{27}$

From the perspective of the legal academy, other markers are relevant, for law professors played an important role in making the federal courts such a prominent institution in the legal landscape. In the wake in 1938 of the promulgation of the Federal Rules of Civil Procedure and through the advocacy of Charles Clark, James William Moore, and others, ${ }^{28}$ first-year courses on procedure came to rely on the Federal Rules of Civil Procedure as their centerpiece. Felix Frankfurter, Harry Shulman, James Landis, Henry Hart, Herbert Wechsler, and others deserve mention for bringing courses on "The Federal Courts" into the curriculum of law schools. ${ }^{29}$ Such courses outnumber those devoted to studying state court procedures, doctrine, and jurisdiction. ${ }^{30}$

\footnotetext{
${ }^{24}$ See Judith Resnik, "Uncle Sam Modernizes His Justice": Inventing the Federal District Courts of the Twentieth Century for the District of Columbia and the Nation, 90 Georgetown L.J. 607 (2002) [hereinafter Resnik, Inventing the Federal District Courts].
}

${ }^{25}$ See The Budget for Fiscal Year 2004, Historical Tables, Outlays by Agencies, 1962-2008. The increase from 1991 to 2002 was almost 100 percent. See Government Accounting Office, An Effective System of Justice, GAO Strategic Plan 2002-2007, available at <http:/www.gao.gov/sp/html/strobj15.html . Note that the numbers in the AO Annual Reports differ slightly from those provided in the Fiscal Budget tables. For example, the AO gives the figure of $\$ 4.71$ billion for 2002 , as contrasted with the $\$ 4.8$ billion figure listed above. The FY 2003 and 2004 budgets rose somewhat. See FY 2004 Appropriations Finally Ok'd; But Courts Still Face Fiscal Threat, 36 Third Branch 1 (Feb. 2004) (describing a 4.7 percent increase in funds from FY 2003 that was 2.3 percent under what was needed to maintain services).

${ }^{26}$ See <http://www.supremecourthistory.org/06_research/06_b02.html>.

${ }^{27}$ The depth and breadth of activities are well summarized in a recent publication: Russell Wheeler, A New Judge's Introduction to Federal Judicial Administration (FJC, 2003).

${ }^{28}$ See James William Moore, The Place of the New Federal Rules in the Law School Curriculum, 27 Georgetown L.J. 884 (1939).

${ }^{29}$ The current edition of the Hart \& Weschler book offers a canonical overview of the subject matter of the course. See Richard H. Fallon, Daniel J. Meltzer \& David L. Shapiro, Hart \& Wechsler, The Federal Courts and the Federal System (5th ed. 2003).

${ }^{30}$ See, e.g., American Association of Law Schools, Directory of Law Teachers, 2002-2003 at $1117-1380$ (listing law professors by the areas in which they teach). More than 600 teachers describe themselves as teachers of federal courts. Id. at 1254-58. About 200 teach local government. Id. at 1330-31. Similarly, more than 600 law professors specialize in federal taxation (id. at 1356-61), whereas approximately 60 are listed under state and local taxation. Id. at 1361-62. 
Current budgets help summarize available resources and their allocation. The federal judiciary's budget (which includes probation officers and federal public defenders) was $\$ 4.6$ billion for 2002-under one-half of 1 percent of a national budget of more than $\$ 800$ billion that year. ${ }^{31}$ The Administrative Office received about $\$ 61$ million and the Federal Judicial Center $\$ 20$ million. ${ }^{32}$ Further, although emptying of trials, some 550 court facilities are in use, as is the Thurgood Marshall Building, from which senior administrators provide services for the more than 30,000 federal judicial staff and the more than 1,600 federal district, magistrate, bankruptcy, and appellate judges dispersed nationwide. One estimate, focused on the ratio between staff and life-tenured judges only, identified 92 support personnel per judge ${ }^{33}$ Such personnel are the predicate to the production, collection, tabulation, and positioning of data.

In contrast, many state courts do not have comparable resources. For example, in addition to whatever research is provided state by state,${ }^{34}$ the NCSC had a budget of $\$ 22$ million that also supported the work of the National Conference of State Supreme Court Justices. ${ }^{35}$ Small research grants are also available from the State

\footnotetext{
${ }^{31}$ See The Budget of the United States for Fiscal Year 2004, Historical Tables 4.1 (Outlay by Agency, 1962-2008).

${ }^{32}$ The FY 2003 Budget and the Federal Judiciary, 35 Third Branch 2 (March 2003).

${ }^{33}$ See William G. Young, An Open Letter to U.S. District Judges, Federal Lawyer 31, 33 (July 2003) [hereinafter Young, Open Letter to U.S. District Judges].

\begin{abstract}
${ }^{34}$ I have not located any national compilation of the total outlays spent in administrative support, research, and teaching for each state's judiciary. Some raw numbers are available, but comparing outlays (state to state or state to federal) is difficult because of variations in sizes of judiciaries, dockets, population rates, legal rights, and infrastructure needs.

For example, in 1999-2000, the California judiciary received some $\$ 118$ million for its Judicial Council, which has a mandate that includes administration, teaching, and research, and therefore is somewhat similar to that of the Administrative Office of the U.S. Courts and of the Federal Judicial Center. California trial courts deal with more than 8.5 million cases a year, as contrasted with under one-half million civil and criminal filings and 1 million bankruptcy petitions in the federal courts. California's judiciary is comparable in size if not somewhat larger than that of the federal courts. California has more than 1,600 judges and another 440 commissioners and referees. See 2001 Judicial Council [of California] Annual Report 5-9, available at <www.courtinfo.ca.gov/reference/documents/ar2001-2.pdf>. In contrast, in New Jersey, where approximately 7 million cases are filed each year, the 2003 judiciary budget was $\$ 504$ million, with $\$ 12.6$ million spent on administration and $\$ 2.5$ million on public affairs and education. See NJ State Budget, Fiscal Year 2003-2004, at D-514, available at <http://www.state.nj.us/treasury/omb/publications/04budget/pdf/ 98.pdf $>$.
\end{abstract}

${ }^{95}$ See National Center for State Courts 2002 Annual Report 20 (2003), available at <http://www. ncsonline.org/D-Comm/Images/NCSC_AnnlRpt2002.pdf>. About half of that amount ( $\$ 10.6$ million) comes from federal grants and contracts, while 44 percent $(9.7$ million) comes from assessments paid by the states. Association fees, conferences, consulting, and private support result in about $\$ 2$ million more. 
Justice Institute, itself operating under a budget that has varied from a high of $\$ 13.5$ million to a low of about $\$ 3$ million. ${ }^{36}$

Turn to organizations that are central advocates for resources to judiciaries. The American Bar Association (with some 400,000 members, paying dues that range from nothing to $\$ 350^{37}$ ) received income from both dues and other sources. It is a “\$180 million-a-year enterprise," with "general revenue expenses of about $\$ 95$ million and section expenses of about $\$ 40$ million." 38 The American Law Institute's yearly budget information indicates that its operating expenses have ranged from about $\$ 4.9$ million (in 2002) to about $\$ 5.2$ million (in 1999), and it has an endowment of more than $\$ 20$ million. ${ }^{39}$ State-focused legal organizations have smaller budgets. The National Conference of Commissioners on Uniform State Laws describes its financial support as coming from state appropriations but explains that it gets "maximum results from a minimum budget because its major asset, drafting expertise, is donated." 40

\footnotetext{
${ }^{36}$ The State Justice Institute (SJI) was founded in 1984 to enable collaboration across states and research on issues of special concern to states. SJI grants have funded many projects, including "futures planning," problems of pro se litigants, and leadership development for state jurists. When best funded (1992-1995), SJI received $\$ 13.55$ million from Congress. State Justice Institute, 13 SJI News 1, 1 (Winter 2002), available at <http://www.statejustice.org/pdf/n/u/3nl.pdf $>$. Between 1987 and 2002, SJl awarded some $\$ 125$ million in grants that supported more than 1,000 projects. See State Justice Institute Reauthorization Act of 2003, H.R. Rep. 108-285, to accompany H.R. 2714, 108th Cong., 1st Sess. at 2 (Sept. 25, 2003) [hereinafter 2003 SJI Reauthorization Act Report].

By the mid 1990s, SJl came under attack. See Malcolm M. Lucas, Don't Pull the Rug from Under the State Justice Institute, Legal Times, Sept. 25, 1995 at 21. In 1996, SJl's budget was cut in half (to about $\$ 6$ million), and until 2001, stayed at about $\$ 6.5$ million. Id. See also 9 SJI News 1,5 (Jan. 1998). In the fall of 2001, Congress again cut its budget in half, to $\$ 3$ million, where it remained. 13 SJI News, 1, 4 (Fall, 2002); Rhonda McMillion, Courting Congress: ABA Works to Preserve Federal Funding for the State Justice Institute, 88 A.B.A.J. 68 (2002).

The 107th Congress required the Attorney General of the United States, working in cooperation with the FJC, to report on the effectiveness of SJI, and his 2002 Report both found SJI effective and noted that support for SJI in turn supported innovation and improvement in state systems, which was "a Federal Interest." 2003 SJI Reauthorization Act Report at 4. The Attorney General also proposed that SJI find ways to involve state members more and disseminate information about its products more widely. Id. at 6 . As of this writing, pending legislation would fund SJI at $\$ 7$ million for fiscal years 2005-2008. Id. at 5 .
}

${ }^{57}$ Amounts vary. For example, a person less than a year after admission to the bar pays nothing, whereas those less than five years after admission pay $\$ 110$, and those 10 or more years after admission pay $\$ 350$. See $<$ http://www.abnret.org/jd/jdjoin.html>.

${ }^{38}$ See Allan J. Joseph, ABA Treasurer's Report 2001-2002, ABA Journal 64 (Feb. 2003).

${ }^{39}$ See American Law Institute, Annual Report: Report of the Treasurer at 3-4, Annex I (2003), and Annual Report: Report of the Treasurer at Annex I (2000), both available at <http://www.ali.org>.

${ }^{40}$ See website of the National Conference of Commissioners of Uniform State Laws Organization, available at <http://www.lectlaw.com/files/org04.hum>. I have yet to locate a master list of each state's appropriations per year. Some data are available state by state. For example, in FY2003, about $\$ 25,000$ was spent by West 
These dollar figures illuminate how the information considered in this Vanishing Trial Symposium came into being. The institutions that gathered the data so thoughtfully interwoven by Professor Galanter had many challenges to overcome. On the federal side, 94 district courts had to be brought under a legal and administrative umbrella so that jurists and clerks would use the same procedures and the same forms. In terms of cross-state comparisons, not all states share the same terms that make easy the counting of "cases." States also do not all have the same reporting periods, nor do they devote equal resources to the study of judicial processes. ${ }^{41}$ As the variation in the kind and quality of information from state to state and as the diversity of local rules within the federal districts and circuits make plain, the project of national, centralized data collection is far from complete, and all of us who work with court data are often distressed by what is missing. ${ }^{42}$ But we also need to appreciate how much has come to light because of the work of lawyers, judges, and academics over the decades past. Today's state and federal judiciaries have the corporate capacity to produce the many tables and charts and reports that form the basis of this Symposium, and that same corporate capacity enables judiciaries to exercise political power. They have the means to create procedures, to define norms of good judging, to educate judges about their jobs, and to forward agendas in state and national legislatures about which litigants should get what kinds of judges. ${ }^{43}$

\section{b. The Absence of an Infrastructure to Assess Agency Adjudication. I turn now to the missing} data from administrative agencies and elsewhere to learn more about and from the

Virginia for its Commission on Uniform State Laws. See Department of Admin., Comm'n on Uniform State Laws, available at <http://www.wvbudget.gov/opdet/uniform.pdf >.

Given the NCCUSL's lower profile in some sectors of the academy, a word about its work is in order. Created in 1892 (and holding its first meeting-as did the ABA-in Saratoga Springs, NY), each jurisdiction (now including the Virgin Islands) sends commissioners to meetings to draft more uniform state law. Commissioners must be members of the bar of the jurisdiction that they represent, and more than 300 serve. The NCCUSL takes credit for drafting "more than 200 uniform laws" related to a wide range of questions, including commercial law, family law, and probate and estate law. Id.

${ }^{41}$ For example, in some states, efforts to reopen judgments in civil cases are counted as new filings, while in many other states such efforts are separately tabulated. See National Center for State Courts, 2002 Jurisdiction and State Court Reporting Practices, Figure H, Method of Counting Civil Cases in State Trial Courts, 2002, at 97-102, in State Court Caseload Statistics, 2003, available at <http://www.ncsconline.org/D_Research/csp/2003_Files/2003_SCCS.html>. Another source of variation comes from different intervals for reporting data. In some states, cases are counted in calendar years beginning on January 1, while others begin on June 1, and still others on either September 1 or October 1. Id. at Figure A, Reporting Periods for all State Courts, 2002, at 63-64. Variation in counting of criminal cases is particularly acute, as states "differ on whether they count charges, defendants, or indictments." Id. at Appendix A, Methodology at 204.

${ }^{42}$ See generally, Theodore Eisenberg \& Margo Schlanger, The Reliability of the Administrative Office of the U.S. Courts Database: An Initial Empirical Analysis, 78 Notre Dame L. Rev. 1455 (2003).

${ }^{43}$ See Resnik, Trial as Error, supra note 8, at $967-91$. 
information gaps themselves. During the 20th century, the legal profession helped create the administrative state. With a vision of an expansionary role for rights and regulations, the profession's leadership shaped new venues for adjudicationagencies, which were the "alternative dispute resolution" (ADR) of their generation.

Interest in the 1920s and 1930s in such alternatives came (as it does today) in part from a desire to avoid the federal judiciary, which was then understood as hostile to segments of disputants, such as laborers. ${ }^{44}$ But also (and again as it is today), proponents sought simplicity and efficiency. Procedures for agencies were formalized in 1946 when Congress enacted the Administrative Procedure Act (APA). That statute empowered a new group, Administrative Law Judges (ALJs), who hold their positions through special selection and retention procedures designed to insulate ALJs from being easily removed by agency managers. ${ }^{45}$

The volume of adjudication within federal agencies is substantial. As Paul Verkuil has pointed out, counting proceedings in administrative venues and comparing them to cases in court venues is complicated. A decade ago, he estimated that "ALJs probably decide more 'cases' each year than do their federal judicial counterparts." ${ }^{\text {A6 }}$ As he and Jeffrey Lubbers explained more recently, focusing specifically on the Social Security Administration (SSA), "no other program of the federal government produces such a large and complicated caseload for the federal courts to review, and ... no other benefit program of the federal government serves over ten million beneficiaries or involves expenditures that will top $\$ 100$ billion in FY 2002." ${ }^{47}$ Further, the "SSA adjudication system is probably the largest system of trial-type adjudication in the world." ${ }^{* 8}$ Yet despite its import and economic girth, a look at the website of this agency underscores the limits of the data available about agency adjudication.

\footnotetext{
${ }^{44}$ See Edward A. Purcell, Brandeis and the Progressive Constitution: Erie, The Judicial Power, and the Politics of the Federal Courts in Twentieth Century America (Yale 2000); Judith Resnik, The Mythic Meaning of Article III Courts, 56 U. Colo. L. Rev. 581, 595-96 (1985) (discussing the dismay when the Supreme Court ruled in Crowell v. Benson, 285 U.S. 22 (1932) that federal courts retained the power to review hearing officers' determinations of jurisdictional facts).
}

${ }^{45}$ Administrative Procedure Act of 1946, Pub. L. 79-404, 60 Stat. 237, now codified as amended at 5 U.S.C. $\S 551$ et seq. (2000).

${ }^{46}$ Paul R. Verkuil, Reflections on the Administrative Judiciary, 39 UCLA L. Rev. 1341, 1343 (1992). Other
researchers have also compiled numbers. See, e.g., Jeffey S. Lubbers, Federal Agency Adjudication: Trying
to See the Forest for the Trees, 31 Fed. B. News \& J. 383 (1984) (commenting that, as of 1984, more than
five times as many administrative law judges served than had in 1947). I have not located a database on ALJs
that is regularly updated.

${ }^{47}$ Paul R. Verkuil \& Jeffrey S. Lubbers, Alternative Approaches to Judicial Review of Social Security Disability Cases, 55 Admin. L. Rev. 731, 738 (2003).

${ }^{48}$ Id. at 759 . 
First, "before 1993, the only data available on the disability determination resided in files compiled at separate stages of the process." Second, (as of this writing) data for 2002 were not available. ${ }^{50}$ Third, the 2001 data do not delineate between cases heard by the Office of Hearing and Appeals (and therefore by an ALJ) and those heard in federal court (and therefore by a magistrate, district court, or circuit judge).$^{51}$ We do know that about 2 million people apply annually for disability benefits. ${ }^{52}$ Some 1,150 ALJs hear more than 500,000 claims per year. ${ }^{53}$ About a fifth of those, or some 100,000 , proceed to a review by an appeals council, with between 8,000 and 15,000 filings thereafter in the federal courts. ${ }^{54}$

And, to learn more about agency adjudication, researchers have to go agency by agency to find, for example, the 78,000 "notices of disagreements" and about 17,000 new appeals in 2002 under the wing of the Veterans' Board of Appeals, ${ }^{55}$ as well as the numbers of filings in other high-volume adjudication agencies, including the Equal Employment Opportunity Commission ${ }^{56}$ and the Immigration and Natu-

\footnotetext{
${ }^{49}$ SSA, 2003 Annual Report of the SSI Program, Part V(C) Appendices-C (Historical Allowance Data), available at <http://www.ssa.gov/OACT/SSIR/SSIO3/AllowanceData.html> (noting also the problems of constructing the database).

${ }^{50}$ Id, at 2.

${ }^{51}$ Id. at $6, \mathrm{n} .5$ (cases beyond reconsideration include those "appealed to the OHA, as well as beyond the OHA to the Federal courts"). Criticism of the multiple layers of decisionmakers has prompied proposals for reforms, including a separate court for Social Security claimants. Opponents argue the import of review by life-tenured judges and point to a 50 percent reversal or remand rate of SSA denials as evidence. See Verkuil \& Lubbers, supra note 47 , at $752-58$.
}

${ }^{52}$ Verkuil \& Lubbers, supra note 47 , at 759 .

${ }^{53}$ Id. See also Explanation of the Appeals Process, SSA Publication No. 05-10041, available at <http://www.ssa.gov/oha/about_oha.html>; Subcommittee on Social Security, House Comm. on Ways \& Means, Statement of the Hon. Ronald G. Bernoski, President, Association of Administrative Law Judges, Sept. 25, 2003 at 5, available at <http://waysandmeans.house.gov/hearings.asp? formmode=details\&hearings=106> [hereinafter 2003 Hearings on the SSA and SSA ALJs].

${ }^{54}$ Verkuil \& Lubbers, supra note 47, at 759-61; SSI Historical Table Appendix tbsl. Cl and C2, supra note 49.

${ }^{55}$ See Report of the Chairman, Board of Veterans' Appeals, Fiscal Year 2002 at 13, 17, available at <http://www.va.gov/Vetapp/ChairRpt/BVA2002AR.pdf.>

${ }^{56}$ See U.S. Equal Employment Opportunity Commission, FY 2002 Annual Report on Federal Work Force, available at <http://www.eeoc.gov/press.7-17-03.html> (discussing the almost 22,000 complaints filed by federal employees); and U.S. Equal Employment Opportunity Commission, FY 2002 Annual Report, available at <http://www.eeoc.gov/abouteeoc/annual_reports/annrep02.html> (discussing the 84,440 charges filed against private-sector employers). Between 9,000 and 12,000 hearings are requested in the federal sector cases over a five-year period, but not all cases go to hearings. For example, in FY2003, about 12,000 resolutions occurred with 16 percent after hearings, 23 percent on the record, 32 percent by settlement, and the remainder either dismissed or withdrawn. Id. at <http://www.eeoc.gov/federal/fsp $2003 /$ sectionc.hml.> "Private-sector" cases are those in which the EEOC reviews charges against private employers. By statute, 
ralization Service (now called the U.S. Citizen and Immigration Service).$^{57}$ No central databases are currently available ${ }^{58}$ because of the lack of umbrella organizations to serve federal and state administrative agencies in a comparable way to what the $\mathrm{AO}$, the FJC, and the NCSC provide for federal and state courts. ${ }^{59}$

Lacking numbers from elsewhere, I will try to supply a general comparison between the volume of "trials" in Article III courts and the four federal agencies mentioned above that do a high volume of adjudication. Caveats are required. Specifically, administrative adjudication covers a range of kinds of cases, with varying levels of proof and lengths of inquiry. Moreover, although the stakes are high for disputants, administrative adjudication is sometimes termed "nonadversarial," in that the government does not necessarily have a representative. Further, the presiding judge has a mandate to develop the record. ${ }^{60}$ Some readers may thus want to discount how much like trials this form of adjudication is, although some scholars of administrative law criticize this process precisely because it is too trial-like. ${ }^{61}$ Moreover, adjudication inside the Article III courts is also a mixture of processes, with unrepresented litigants appearing in increasing numbers and trial judges sometimes lending assistance. In

individuals must exhaust this administrative route (in pursuit of help and/or a "right-to-sue" letter) prior to filing a federal lawsuit. The EEOC is also empowered to bring claims in its own name and to intervene. In FY 2002, more than 84,000 such charges were filed. The EEOC runs a national mediation program that resulted in 7,858 resolutions in that year, providing $\$ 111.5$ million in benefits. See <www.eeoc.gov/ mediate/mediator-stats.html>.

\footnotetext{
${ }^{57}$ About 220 immigration judges, serving outside the APA, deal with more than 200,000 proceedings annually. Gary J. Edles, An APA-Default Presumption for Administrative Hearings: Some Thoughts on "Ossifying" the Adjudication Process, 55 Admin. L. Rev. 787, 810-11 (2003). In FY2003, immigration "court matters" totaled 290,628 "receipts," with 296,494 "completions," and the Board of Immigration Appeals received 41,907 filings, and completed 48,060. See U.S. Department of Justice, Executive Office for Immigration Review Fiscal Year 2003 Statistical Yearbook B2 and S2 (2004), available at <http://www.usdoj.gov/ eoir/statspub/fy03syb.pdf.>

Receipts and completions represent cases, with each case involving "one lead alien" and sometimes other family members. See U.S. Dep't of Justice, Executive Office of Immigration Review, 2001 Statistical Year Book (Mar, 2002) at C-2, available at <www.usdoj.gov/eoir/statspub/fyolsyb.pdl>. In 2001, the Immigration Court decided 216,319 cases. Id. at I-3. Decisions after hearings in FY2001 numbered about 157,000 with the remaining 59,000 completions accomplished through "administrative closure or change of venue." Id. at I-1. In some of the hearings, the alien does not appear and the case is conducted as an "in absentia hearing," with a high standard of proof; about 42,000 cases were so decided in 2001 . Id. at $\mathbf{L}-1$. About 48,000 cases involved asylum claims, with individuals seeking a right to remain in the United States because of a fear of harm were they to return to their country of origin. Id. at M-1. About 10,000 hearings occur in jails or prisons where incarcerated criminal aliens are housed. Id. at U-1.
}

${ }^{58}$ For example, the website of the Office of Personnel Management (OPM), charged with running the application process for the selection of ALJs, does not yield an overview of the numbers of judges in each agency or the quantum of work done. See <http://www.opm.gov>.

${ }^{59 u}$ Private ${ }^{n}$ associations of state and federal administrative law judges exist, as they do for federal judges, and work on issues related to salaries, ethics, and independence.

${ }^{60}$ Edles, supra note 57 , at 809 .

${ }^{61}$ Id. at $796-97$. 
Figure 1: Authorized federal judgeships, including Article I courts and administrative law judges, nationwide: 2001

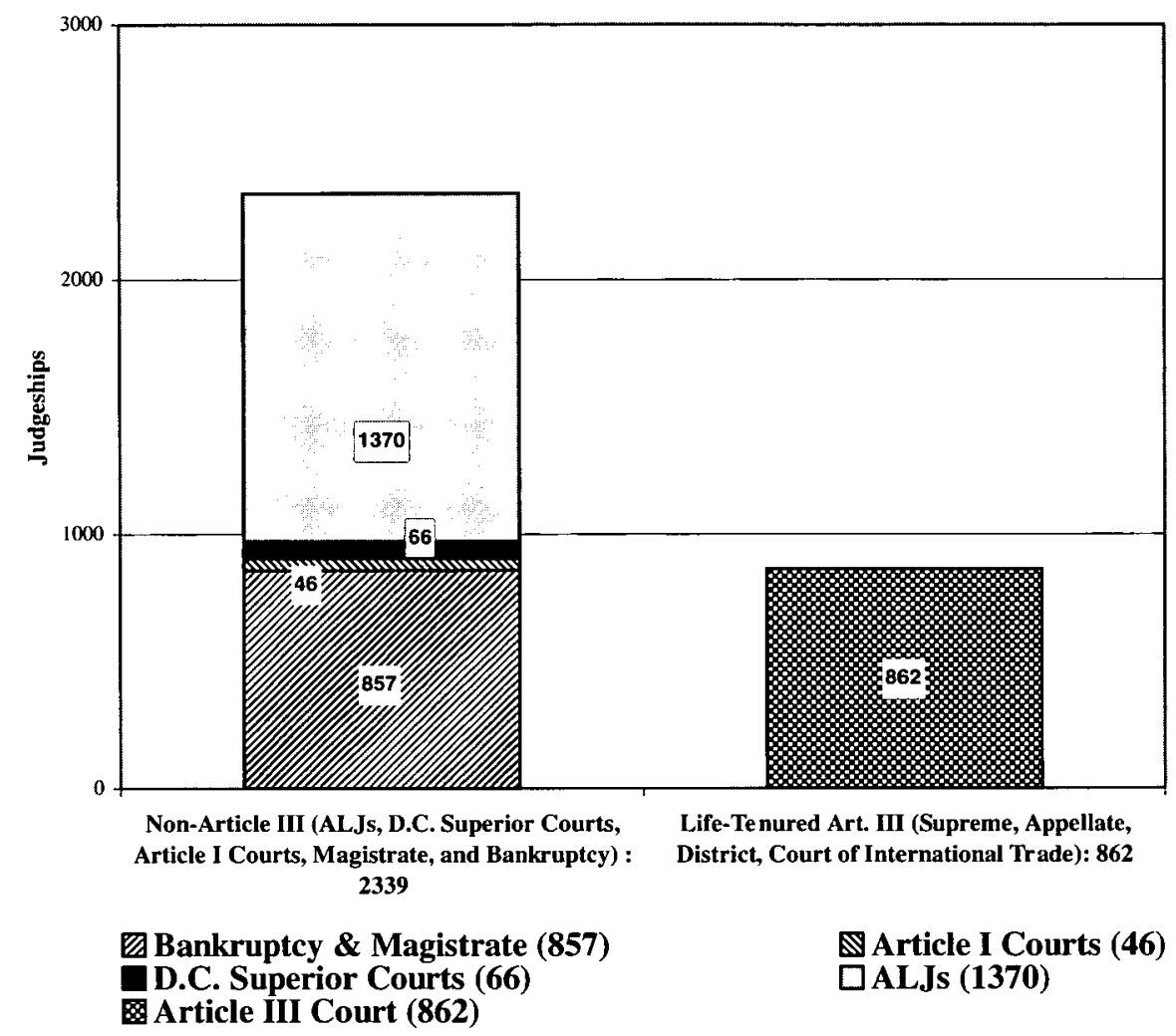

addition, the term "trial" in the statistics on the federal courts does not only include proceedings that result in "jury verdicts or other final judgments"; also counted as trials are "contested hearings at which evidence is presented."

Turn then to the rough numbers. In 2001, Article III judges concluded about 13,500 such trials. Magistrate judges conducted another 10,000, and bankruptcy judges closed just under 60,000 "adversary proceedings," 63 yielding about 85,000 proceedings. In contrast, SSA ALJs concluded about 465,000 cases, immigration judges another 215,000, with about 31,000 decisions coming from the Board of Veterans' Appeals, and about 9,400 from the EEOC, yielding an estimate of more than 720,000 proceedings. In short, a good deal of adjudicatory activity remains to be analyzed and understood. (See Figures 1 and 2.)

\footnotetext{
${ }^{62}$ Administrative Office of the U.S. Courts, Judicial Business of the U.S. Courts, 2001 at 24-25.
}

${ }^{63}$ Id. at 25,30 . 
Figure 2: Estimate of adjudiatory proceedings in Article III courts and in four federal agencies: 2001

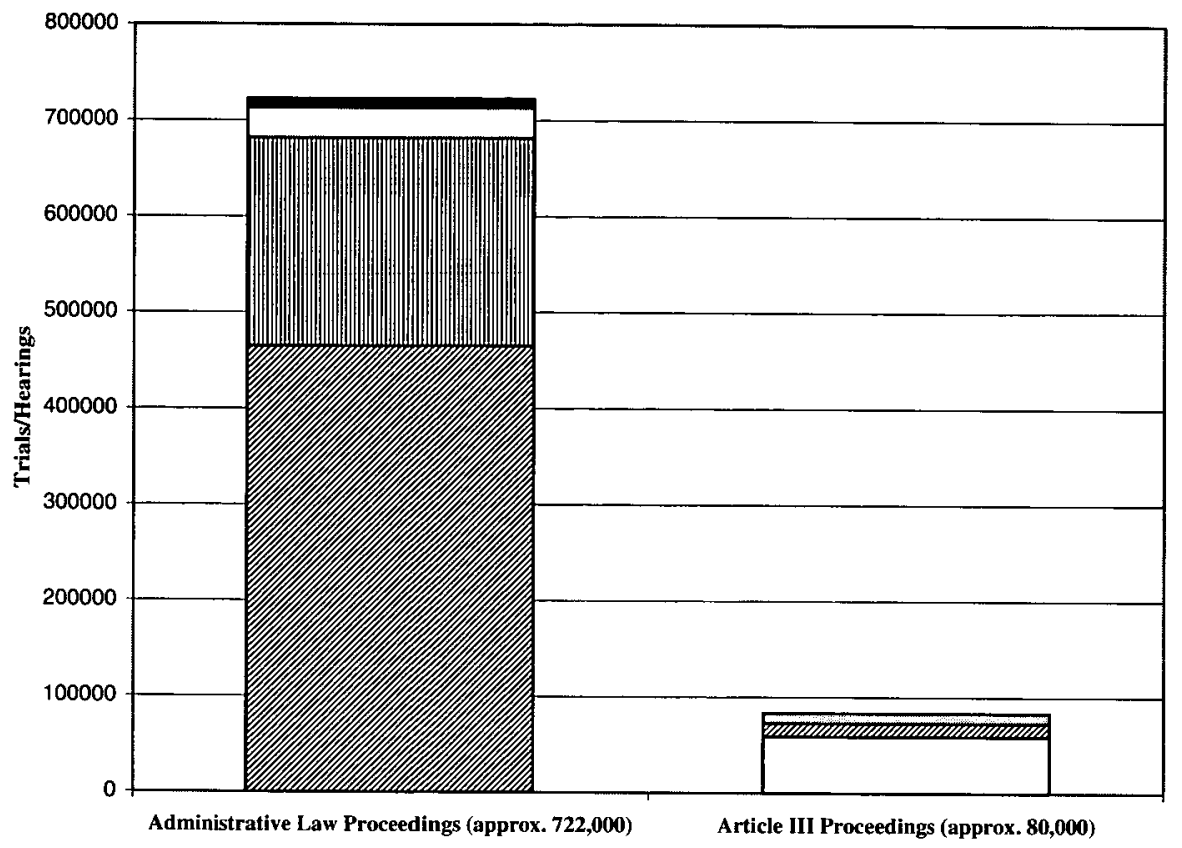

Social Security Administration (SSA)

milmmigration and Naturalization Services (INS)

$\square$ Board of Veterans' Appeals (BVA)

$\square$ Bankruptcy Judges

District Judges

$\square$ Magistrate Judges

Equal Employment Oportunity Commission (EEOC)

Why is our knowledge of these many proceedings so minimal? For a time, during the almost 30 years when the federally charted Administrative Conference of the United States (ACUS) was funded, ${ }^{64}$ the ACUS had the potential to provide analy-

\footnotetext{
${ }^{64}$ Congress established the Administrative Conference of the United States in 1964. See Administrative Conference Act, Pub. L. No. 88-499, 78 Stat. 615 (1964), codified as amended at 5 U.S.C. $\$ 591$ et seq. (2000). That body grew out of temporary institutions established under the Eisenhower and Kennedy Administrations and at one point located within the Deparument of Justice. See Toni M. Fine, A Legislative Analysis of the Demise of the Administrative Conference of the United States, 30 Ariz. St. L.J. 19, 26 (1998). Congress delayed funding the Conference, apparently awaiting President Johnson's nomination of a chair, until 1968. Id. at $28, n$. 25 and at 115 .
} 
sis for federal agencies. The ACUS had a structure that might have made it another pillar of the legal establishment. Its chair and an 11-member council were appointed by the president upon confirmation by the Senate. ${ }^{65}$ Their charge was to bring government and private-sector participants together in an assembly of between 75 and 100 members to make recommendations about how to better federal agency procedures. ${ }^{66}$ The ACUS addressed a range of topics, from procedures for Social Security decision making to the Freedom of Information Act and the role of whistleblowers. During its tenure, the ACUS proposed elimination of the amount in controversy requirement for suits filed under the Administrative Procedure Act, ${ }^{67}$ an increase in administrative agencies' punitive capacities, ${ }^{68}$ and an enhancement of powers to enforce environmental laws. ${ }^{69}$ Of the more than 200 recommendations made, many were implemented, at least in part. $^{70}$

\section{4 cont.}

Congress eliminated funding in 1995 , at which point the ACUS had a budget of $\$ 1.8$ million. Id. at 115, n.369. The Committee report that cut the ACUS stated that the termination recommendations were "consistent with the Committee's findings that certain programs" were no longer necessary, were duplicative, or that their functions were "no longer an appropriate federal expense." See H.R. Rep. 104-183, 104th Cong., 1st Sess. 1995, 1995 WL 419051 at 4, Pub. L. No. 104-52, 109 Stat. 468, Treasury, Postal Service and General Government Appropriation Bill (1996). See also Victor G. Rosenblum, Contrasting Perspectives on the Deeds and Demise of the Administrative Conference: Is There a Determinable Legacy?, 30 Ariz. St. L.J. 1 (1998).

${ }^{65}$ Details of the structure and the charter are also provided at H.R. Rep. 101-1015, 1991 WL 4376 (Jan. 1991).

${ }^{60}$ The chair, as the chief executive official, was charged with creating a staff that would, with consultants, investigate and research topics of relevance and report to the Council. As to the leadership positions on the Council, the chair alone drew a salary. Pub. L. No. 88-499, 78 Stat. 615 (1964), codified as amended at 5 U.S.C. \$\$591-593. A ceiling on expenditures was imposed, first set at $\$ 250,000$ and eventually raised to $\$ 3$ million before declining to $\$ 1.8$ million prior to being de-funded. See Fine, supra note 64 , at $35-42,115$ (Appendix) (listing the appropriations for the ACUS for each year).

\footnotetext{
${ }^{67}$ See Administrative Conference of the United States, Recommendation 68-7; 1968 ACUS 22; Administrative Conference of the United States, Recommendation 69-1; Statutory Reform of the Sovereign Immunity Doctrine, 1969 ACUS 23.
}

\footnotetext{
${ }^{68}$ See Administrative Conference of the United States, Recommendation 72-6: Civil Money Penalties Sanction, 1972 ACUS 67. Some 200 statutes did change thereafter. See William Funk, R.I.P. A.C.U.S., 21 Admin. \& Reg. L. News (No. 2, Winter 1996) available at <http://www.abanet.org/adminlaw/news/ vol21no2/acus_rip.htmb.

${ }^{69}$ Administrative Conference of the United States, Recommendation No. 85-3, Coordination of Public and
Private Enforcement of Environmental Laws, 50 Fed. Reg. 28,366 (1985).

${ }^{70}$ Funk, supra note 68 .
} 
The ACUS might have been the institution to provide links between the many individual databases of agencies. However, the ACUS was never well funded. ${ }^{71}$ Further, critics complained that the ACUS was insufficiently responsive to concerns of various agencies. ${ }^{72}$ Others were unenthusiastic about its agendas aimed at augmenting agency capabilities and capacities. In 1995, Congress stopped its support of the ACUS altogether. ${ }^{73}$ Although the ABA has tried to take up some of the slack by providing information about federal adjudication ${ }^{74}$ and has advocated for renewal of the ACUS, ${ }^{75}$ Congress has not provided funding, resulting in the absence of any federal institution charged with considering the role and function of administrative adjudication.

Similarly, no such organization exists that tracks information on agency adjudication across the states. Moreover, Congress has not been generous to the State Justice Institute, which was once barely surviving and is still working with much reduced budgets, ${ }^{76}$ and therefore is less able to provide much by way of direct support for interjurisdictional collaboration and research. As a consequence, a large quantum of adjudicatory-like decision making goes uncompiled, underrecorded, and minimally represented within the world of elite legal institutions.

Of course, significant segments of the bench, bar, and academic communities do attend to administrative agencies. Indeed, the ABA's Section of Administrative

\footnotetext{
${ }^{71}$ According to one report, the total funds allocated to ACUS between 1968 and 1994 were about $\$ 300$ million. See James Warren, Congress Eliminates a Department. That Actually Worked, Chi. Trib. Nov. 12, 1995 (Perspective) at $C 2$ (comparing the billions spent on defense research).

${ }^{72}$ See, e.g., Jerry L. Mashaw, Reforming the Bureaucracy: The Administrative Conference Technique, 26 Admin. L. Rev. 261 (1974); Warner W. Gardner, A Review of the Work of the Administrative Conference, 26 Admin. L. Rev. 281 (1974). See also Paul Verkuil, Speculating about the Next "Administrative Conference": Connecting Public Management to the Legal Process, 30 Ariz. St. L.J. 187 (1998).

${ }^{79}$ See 141 Cong. Rec. H10,813-05, H10,824 (daily ed. Oct. 25, 1995). See Now More than Ever: Reauthorizing the Administrative Conference, Reforming Regulation, and Reinventing Government, 8 Admin. L.J. Am. U. 677 (1994).

${ }^{74}$ See, e.g., A Guide to Federal Agency Adjudication (Michael Asimow ed., Section of Administrative Law and Regulatory Practice, ABA, 2003).

${ }^{75}$ See ABA, Section of Administrative and Regulatory Practice, A Report for the President-Elect of the United States, 52 Admin. L. Rev. 1099, 1108-09 (2000).

${ }^{76}$ See 2003 SJI Reauthorization Act Report, supra note 36, at 12 (supporting an increase of SJl's budget to $\$ 7$ million). Representative Smith described the proposed appropriation as appropriate for this "small, but important, organization that assists our State court systems." Id. Indicative of the low visibility of SJI, when Attorney General John Ashcroft was asked about SJ1, he commented that he was not "aware of it." Hearings of the Commerce, Justice, State, \& the Judiciary Subcommittee of the Senate Appropriations Committee, Appropriations for the Justice Department, Testimony of Attorney General Ashcroft, Fed. News Serv. at 8 (Apr. 1, 2003).
} 
Law \& Regulatory Practice is a leading voice, now debating recommendations on adjudication under the APA. ${ }^{77}$ But it has not been able to sustain the kind of political commitment required to garner the resources requisite to making agency adjudication as visible as that of courts. The reasons are many. First, unlike general jurisdiction courts, presumed to affect diverse segments of the population, agencies are segmented by topic, resulting in segmented sets of constituents. Elite lawyers appear regularly before some agencies but not before others. Second, as regulatory activities at some agencies declined, lawyer services and attention went elsewhere. Third, aggressive agency regulation became politically controversial, making it complex for mainstream institutions to support. Fourth, some of the small-value claims that were and are a staple of agency caseloads have less relevance to the leadership of the legal profession. Fifth, some groups may feel that their interests are well served by agencies whose judgments receive relatively little systematic scrutiny.

As a consequence, agency adjudication remains something of a backwater, with narrow legal mandates to do law interpretation and little cultural capital. Although some agencies deal with well-to-do disputants (e.g., on matters of energy regulation and the securities industry), the volume of disputes in that sector is small compared to that of agencies dealing with more marginal claimants. High-end disputants, assisted by lawyers, sometimes have the capacity to select between agencies and courts or move back and forth. Those who must remain inside agency processes have their claims determined at initial and sometimes appellate stages by administrative law judges chartered under the APA. These judges are selected through a competitive examination and interview process. In contrast, Article III judges are selected by presidential nomination and senatorial confirmation process; magistrate and bankruptcy judges in turn gain their charters through selection by Article III judges. ${ }^{78}$ ALJs also work in a more bureaucratic structure than do judges in courts. Further, ALJs are paid less well (in terms of salary, staff, space, and public attention) than many judges based in courts. Moreover, a good deal of adjudicatory work is also done by lower echelon employees-administrative judges, hearing examiners, and the like. Yet, agencies are "the courts" for thousands who contest Social Security allocations or veterans' benefits and who have to negotiate their taxes or their status as citizens and aliens.

\footnotetext{
${ }^{77}$ See Michael Asimow, Section Seeks Input on Proposals to Reform APA Adjudication Provisions, 29 Admin. \& Reg. L. News 28 (Spring 2004); Michael Asimow, Whither APA Adjudication?, 28 Admin. \& Reg. L. News 7 (Summer 2003) (both discussing proposals to require APA protections to non-ALJ hearings, estimated to be more than one-half million yearly); Edles, supra note 57 , at 788-89 (objecting to a resolution adopted in 2000 by the $A B A$ that, absent statutory language to the contrary, all administrative hearings be subject to the APA's requirements for formal hearings).
}

${ }^{78}$ For details, see Resnik, Inventing the Federal District Courts, supra note 24, at 669-79. 
Backwater adjudication is not limited to agencies. Court systems also have more and less prestigious assignments, and prestige often tracks forms of wealth. Lowerstatus cases involve disputants who have claims of relatively small economic value and who are assisted either by lawyers with fewer resources or no lawyer at all. Moreover, certain arenas of law, such as conflicts around family life, are perceived to be less "law-like" and therefore less appealing to segments of the bar and the judiciary. The diversification of venues for adjudication has generated even greater hierarchies of adjudication than have existed within tiered court systems.

Thus we work with data produced through this reflexive circle of particular sets of interests, ${ }^{79}$ and hence we are especially rich in understanding the federal courts, ${ }^{80}$ relatively rich in information about state courts, and unable to make generalizations about the myriad of events outside of those buildings. We simply know little about the many public "courts" outside "the courts."

\section{B. The Proliferation of Trials and the Political Significance of Adjudication}

The argument that, in fact, trials may have multiplied (albeit outside of courts as traditionally defined) relies not only on unearthing the tens of thousands of trials outside of courts but also on the political significance of the core aspects of trials and of the adjudicatory project for which they stand. We live in a world saturated with people holding themselves out as dispute resolvers. Courts could be understood as having "outsourced," with forms of decisionmaking mimicking adjudication becoming commonplace in many institutions from public agencies to universities to private employers. ${ }^{81}$ As suggested by the words migrating and morphing in this article's title, these alternatives (even "rent-a-judge") can be read as enhancing the capacity to hold trials, albeit ones that look somewhat different from those held in courts. The proliferation and relocation could be understood as demonstrating the need for more adjudication or for more hospitable (translated sometimes as less expensive, sometimes as more private, sometimes as more controlled) environs, rather than as a rejection of the values for which trials stand.

A fair account of major legal events of the 20th century substantiates adjudication's great political and popular success-demonstrated not so much by what is happening in federal courts but by what is happening in so many other venues in

\footnotetext{
${ }^{79}$ See generally, Pierre Bourdieu, The Force of Law: Towards a Sociology of the Juridical Field, in translation at 38 Hastings L.J. 805 (1987).

${ }^{80}$ Data gaps are of course everywhere. All of us who have done empirical work on court-based processes are keenly aware of the "missing data" within courts, but my point here is comparative.

${ }^{81}$ See, e.g., Katherine V.W. Stone, The New Psychological Contract: Implications of the Changing Workplace for Labor and Employment Law, 48 UCLA L. Rev. 519 (2001).
} 
and outside the United States. ${ }^{82}$ Return to the factors that I detailed at the outsetthe changes in conceptions of state obligations to individuals, rightsholding by women and by peoples of all ages and colors, and the possibilities of technology, regulation, and law making enhanced through the expansion of the bar and the professionalization of the judiciary. Those predicates support a narrative of an expansionary adjudicatory project premised on widespread acceptance of the desirability of adjudication as a process for making decisions enforced by the state. Moreover, events from the last century provide a good deal of evidence of a radical normative reorientation that has prompted the formulation of adjudicatory processes to hosts of new claimants through the creation of new kinds and forms of judging.

The 1938 Federal Rules of Civil Procedure provide one starting point. Their drafters created a trans-substantive code to simplify process, to ease access to courts, and to collapse distinctions between law and equity. With their flexible, equity-based approach aimed at diminishing formalism, ${ }^{83}$ these rules put trial judges front and center and endowed them with a good deal of discretion to tailor processes to the circumstances of a particular case.

The positive normative vision of adjudication can be seen in the responsibility that Congress vested in judges to elaborate rights. Recall that at the turn of the last century, a struggle ensued in the United States between a growing national bar and some populist members of Congress leery of decision making in Washington. ${ }^{84}$ Remember that around 1900 , the federal judiciary numbered under 100 , total ${ }^{85}$ The national lawyers won. In 1922, Congress began what became a great expansion project, adding to the ranks of life-tenured federal judges, ${ }^{86}$ today numbering more

\footnotetext{
${ }^{82}$ See generally, Benedict Kingsbury, The International Legal Order, in The Oxford Handbook of Legal Studies 271-97 (Peter Cane \& Mark Tushnet eds., 2003).

${ }^{8 *}$ The new rules relaxed pleading requirements but imposed obligations on adversaries to exchange information-both written and oral-about the facts and law in dispute. The concept of lawyers and judges meeting (the "pretrial") was borrowed from practices of state courts and the English system, whereas the mandated disclosure of information ("discovery," accomplished through interrogatories, in-person depositions, production of documents, examination of physical evidence, and admissions) was largely an invention of the 1938 rules. See generally, Stephen N. Subrin, How Equity Conquered Common Law: The Federal Rules of Civil Procedure in Historical Perspective, 135 U. Pa. L. Rev. 909 (1987); Stephen Burbank, Of Rules and Discretion: The Supreme Court, Federal Rules, and Common Law, 63 Notre Dame L. Rev. 693 (1988).
}

${ }^{84}$ See Subrin, supra note 83, at 135 U. Pa. L. Rev. at 943-44, 955 (discussing the conflict).

${ }^{85}$ See Resnik, Inventing the Federal District Courts, supra note 24, at 612-13.

${ }^{86}$ See Act of Sept. 14, 1922, ch. 306, $\$ 1,42$ Stat. 837, 837-38 (1922) (creating 24 additional judgeships). The Act also created the Conference of Senior Circuit Judges, the forerunner of what is now called the Judicial Conference of the United States. Id. at $\$ 2$, now codified as amended at 28 U.S.C. $\$ 331$ (2000). 
than $1,000 .^{87}$ In 1934 , Congress gave power to the Supreme Court to promulgate federal rules-thereby displacing and replacing local practice with national norms. ${ }^{88}$ One rationale was technocratic and managerial. Judges turned to the language of business as they sought to make their processes efficient and modern. ${ }^{89}$

But those terms are insufficient to capture all of the agendas, for, in the wake of the Depression, many saw federal governance as a necessary and desirable response to political and economic conditions. An expansion of federal jurisdiction was a mechanism by which to spread and enforce a national legal regime. In the 1940 s, the civil rights movement turned to the federal courts and, by the Warren era, constitutional interpretation looked favorably on court-based processes to enable racial equality and to enhance human dignity. Congress not only supported but expanded this project, time and again authorizing government officials and private parties to bring lawsuits as a means of enforcing federal law..$^{90}$ In short, federal procedure was a piece of a larger constitutional project.

Consider also the overhaul of criminal litigation. The procedural requirement of a "right to counsel"91 that had sat substantively vacant in the U.S. Constitution for almost 200 years suddenly was given new meaning. The Constitution was read to mandate equipage, to insist on state subsidies for criminal defendants and federal rights to process. Gideon $v$. Wainwright ${ }^{92}$ and Brady $v$. Maryland ${ }^{93}$ required that indigent criminal defendants be provided with state-paid lawyers, who (in theory) were to be accorded respect, some flexibility, and information by prosecutors. This interpretation of the Constitution was part of the Court's insight that some states had used their criminal justice apparatus to enforce systems of racial inequality, ${ }^{94}$ just as the contemporary refusal to intervene in criminal justice processes bespeaks a narrowed

\footnotetext{
${ }^{87}$ See Resnik, Inventing the Federal District Courts, supra note 24 , at 614-22.

${ }^{88}$ Rules Enabling Act, Pub. L. No. 73-415, 48 Stat. 1064 (1934), codified as amended at 28 U.S.C $\$ 2071$ et seq. (2000).

${ }^{89}$ In the 1960 s and thereafter, federal courts also adopted individual calendar systems so that a judge assigned at the outset of a case would have responsibility for it from filing to disposition, thereby enhancing judicial authority over its processing. See Judith Resnik, Managerial Judges, 96 Harv. L. Rev. 374, 395-401 (1982); Resnik, Trial as Error, supra note 8, at $935-47$.
}

\footnotetext{
${ }^{90}$ Between 1974 and 1998, Congress created more than 470 new federal causes of action. Administrative Office of the U.S. Courts, Revision of List of Statutes Enlarging Federal Court Workload (Sept. 18, 1998) (memorandum tracking statues and updated periodically). On file with the author.
}

${ }^{91}$ U.S. Gonst., amend. VI.

92372 U.S. 335 (1963).

${ }^{99} 373$ U.S. 83 (1963).

${ }^{94}$ See, e.g., Henry v. Mississippi, 379 U.S. 443 (1965). 
vision of the constitutional obligation to insist on equality. ${ }^{95}$ Federal judges also took a leadership role in pressing Congress to create federal public defender offices. ${ }^{96}$

Then the idea shaped in the criminal context that individuals ought to be empowered and equipped in the contest with the state migrated to the civil side. The Supreme Court-borrowing Professor Charles Reich's insight that statutory entitlements were forms of "property" to be protected from state deprivation by "due process of law" ments employ judicial modes of process to ensure fairness. Goldberg $v$. Kelly $y^{98}$ is the obvious shorthand here, as during the 1970s the template for adjudication provided by the federal rules was applied in some respects to the administrative context.

Other kinds of civil litigation started to look different in light of an understanding of the obligation to equip litigants and to welcome them as rightsholders. The project was not confined to conflict with the state, for the goals were broader: to facilitate the ability to pursue rights when disputing others. Access fees to courts were modified, mostly by statute..$^{99}$ Congress established the Legal Services Corporation, ${ }^{100}$ and a very small sliver of civil litigants-parents faced with state efforts to terminate their rights to be legal parents-were sometimes required, by federal constitutional law, to have state-paid lawyers. ${ }^{101}$

\footnotetext{
${ }^{95}$ See, e.g., McCleskey v. Kemp, 481 U.S. 279 (1987).

${ }^{96}$ See Criminal Justice Act (CJA), 18 U.S.C. $\$ 3006$ A, first enacted in 1964. See Pub. L. 88-455, § 2, Aug. 20, 1964, 78 Stat. 552. The Judicial Conference, working with the Department of Justice, helped to shape that legislation. See Bills to Provide for the Representation of Indigent Defendants in Federal Criminal Cases: Hearings on H.R. 398 \& H.R. 2091 Before Subcomm. No. 4 of the House Comm. on the Judiciary, 83rd Cong., 31-37 (1951) (statements of John J. Parker and John Biggs, Jr., at 31-37 and 54-57). See also Report of the Committee to Implement the Criminal Justice Act of 1964, reproduced at 36 F.R.D. 277, 285-390 (1965) (describing the judiciary's initial implementation efforts).
}

${ }^{97}$ See Charles A. Reich, The New Property, 73 Yale L.J. 733 (1964).

${ }^{98} 397$ U.S. 254 (1970). See Judith Resnik, The Story of Goldberg: Why this Case is Our Shorthand, in Civil Procedure Stories 455-88 (Kevin M. Clermont ed., 2004).

\begin{abstract}
${ }^{99}$ Constitutional obligations to require fee waivers were imposed in only limited areas. See Boddie v. Connecticut, 401 U.S. 371 (1971), as narrowed by Ortwein v. Schwab, 410 U.S. 656 (1973) and United States v. Kras, 409 U.S. 434 (1973). Statutory provisions can be found at 28 U.S.C. $\$ 1915$, which was narrowed as amended in the Prison Litigation Reform Act, Pub. L. No. 104-134, $\$ 804,110$ Stat. 1321 (1996). Congressional authorization for fee waivers dates back to the Act of July 20, 1892, ch. 209, 27 Stat. 252, which provided that any "poor citizen" could commence or prosecute a claim without paying fees. See John MacArthur Maguire, Poverty and Civil Litigation, 36 Harv. L. Rev. 361 (1923). Legislation made such provisions available in appellate litigation. See Act of July 1, 1918, ch. 113, 40 Stat. 634, 683.
\end{abstract}

${ }^{100}$ See Legal Services Corporation Act of 1974, Pub. L. No. 93-355, 88 Stat. 378, codified as amended at 42
U.S.C. $\& 2996$ et seq. $(2000)$.

${ }^{10}$ See Lassiter v. Department of Soc. Servs., 452 U.S. 18 (1981); M.L.B. v. S.L.J., 519 U.S. 102 (1996). 
Aggregate processing became another vehicle by which to enhance access. Class actions generate subsidies for litigants by relying on economies of scale to get a small cadre of lawyers to serve a wider set of claimants. ${ }^{102}$ In the $1960 \mathrm{~s}$, the federal rules were modified to facilitate large-scale litigation. The new class-action rule, complemented by statutes authoring consolidation across federal district courts, ${ }^{103}$ reshaped our imagination about what litigation might accomplish. ${ }^{104}$ Proceedings with hundreds and thousands of individuals, some in search of institutional reform and some in search of money, became commonplace. These mega cases soon overshadowed-in the press, in popular imagery, and in law schools-the small-value Social Security claimant pitted against a sole adversary, even if that adversary was the state.

Markers of success for this expansionist adjudicatory project include congressional creation of new federal rights and the filing of more cases. The legislature embraced adjudication by authorizing litigants to bring a widening array of lawsuits aimed at enforcing civil rights, environmental rights, consumer rights, and worker rights. Between the 1960 s and the 1990 s, caseloads within the federal system tripled, as hundreds of new statutory causes of action were enacted. ${ }^{105}$ Demand soon outstripped the capacity of the life-tenured judiciary, even as Congress was greatly augmenting its ranks. Life-tenured judges worked in tandem with Congress to manufacture non-life-tenured auxiliary judges, magistrate and bankruptcy judges, administrative law judges, hearing officers, and the like-all of whom today comprise a workforce of some 4,000 federal adjudicators committed to this national project. ${ }^{106}$

Further, the rise of ADR has added yet other decisionmakers to the warehouse. As courts insist that disputants use nonadjudicatory mechanisms that resemble private dispute resolution but stem from state-based rules of process rather than from

\footnotetext{
${ }^{102}$ See generally, Judith Resnik, Money Matters: Judicial Market Interventions Creating Subsidies and Awarding Fees and Costs in Individual and Aggregate Litigation, $148 \mathrm{U}$. Pa. L. Rev. 2119 (2000).

${ }^{109}$ See the Multidistrict Litigation Act, Pub. L. No. 90-296, 82 Stat. 109, codified as amended in 28 U.S.C. $\$ 1407$ et seq. (first enacted 1968).

${ }^{104}$ See Fed. R. Civ. P. 23, as amended in 1966. See generally, Judith Resnik, From Cases to Litigation, 54 Law \& Contemp. Prob. 5 (1981); Owen M. Fiss, The Political Theory of the Class Action, 53 Washington \& Lee L. Rev. 21 (1996).

${ }^{105}$ Resnik, Trial as Error, supra note 8, at 955-56.

${ }^{106}$ See Patrick E. Higginbotham, Bureaucracy-The Carcinoma of the Federal Judiciary, 31 Alabama L. Rev. 261 (1980); Owen Fiss, The Bureaucratization of the Judiciary, 92 Yale L.J. 1442 (1983); Patricia Wald, The Problem with the Courts: Black-Robed Bureaucracy or Collegiality Under Challenge?, 42 Md. L. Rev. 766 (1983).
} 
disputants' contractual agreements, ${ }^{107}$ courts legalize "private" dispute resolution. In addition, models of fairness predicated on adjudicatory norms now reach into workplaces, reconfiguring to include their own dispute resolution systems. ${ }^{108}$ And in the free-standing ADR as well as in court-connected programs, the processes are increasingly dominated by professional lawyers and judges and increasingly complex, such that ADR becomes more like adjudication and continuous with it. ${ }^{109}$

Moreover, this discussion ought not remain parochial, focused solely on the United States. Rights-seeking has its roots in the anti-slavery and feminist struggles of the $17 \mathrm{th}, 18 \mathrm{th}$, and $19 \mathrm{th}$ centuries. ${ }^{110}$ In the wake of the rise of fascism and World War II, the United Nations promulgated the Universal Declaration of Human Rights, and the contemporary human rights movement took shape. ${ }^{111}$ Central to its tenets are public adjudicatory processes, particularly but not exclusively for conflicts against the state. ${ }^{112}$ Covenants promulgated through the United Nations announce rights to fair and public hearings to protect equality before the law and to put the judiciary and judicial independence at the fore. ${ }^{113}$

In 1985, the United Nations issued 20 "basic principles on the independence of the judiciary" to underscore both the import of judges and the need to secure

\footnotetext{
${ }^{107}$ Included are not only disputants with preexisting and ongoing relationships but also individuals who, prior to the conflict, were strangers to each other. Compare Owen M. Fiss, The Social and Political Foundations of Adjudication, 6 Law \& Hum. Behav. 121 (1982).

${ }^{108}$ See Katherine Van Wezel Stone, Widgets to Digits: Employment Regulation for the Changing Workplace (Cambridge U. Press, 2004).

${ }^{109}$ See, e.g., National Alternative Dispute Resolution Advisory Council, A Framework for ADR Standards: Report to the Commonwealth Attorney General (Canberra, Australia, Apr. 2001); Yves Dezalay \& Bryant G. Garth, Dealing in Virtue: International Commercial Arbitration and the Construction of a Transnational Legal Order 54-62 (U. Chi. Press, 1996) (describing "arbitration as litigation"); Deborah R. Hensler, A Research Agenda: What We Need to Know about Court-Annexed ADR, Disp. Resol. Mag. Fall 1999, at 15; Nancy A. Welsh, Making Deais in Court-Connected Mediation: What's Justice Got to Do With It?, 79 Wash. U. L.Q. 787 (2001).
}

${ }^{110}$ See Judith Resnik, Sisterhood and Sovereignty: American Lawmakers' Responses to Twentieth Century Women's Rights Claims, in Sisterhood and Slavery (Katherine K. Sklar \& James Stewart eds., forthcoming Yale Press, 2005).

${ }^{11}$ See Resnik \& Suk, Dignity and Sovereignty, supra note 4, at 1925-28.

${ }^{112}$ Article 10 of the Universal Declaration reads: "Everyone is entitled in full equality to a fair and public hearing by an independent and impartial tribunal, in the determination of his rights and obligations and of any criminal charge against him." G.A. Res. 217A (III), U.N. Doc A/810 (1948).

${ }^{113}$ See Art. 14 of the International Covenant on Civil and Political Rights, U.N. Doc. A/6316 (adopted 1966, entered into force 1976), providing that "everyone shall be entitled to a fair and public hearing by a competent, independent and impartial tribunal established by law" and providing specific reasons for exclusion of the press and the public in cases involving morals, private lives, and national security or in the interests of justice. 
their protection against the very governments that deploy them. ${ }^{114}$ The packet includes guarantees on judicial terms of service, powers of finality, and mechanisms to ensure autonomy. Procedures for "effective implementation" include the deployment of a special rapporteur to monitor and to assess compliance. ${ }^{115}$ The UN issues reports to evaluate judiciaries in terms of corruption, accountability, and independence. ${ }^{116}$

Other transnational documents, as well as legal charters and decisions from many countries, announce understandings-predicated on a mixture of constitutional and natural law-of a judiciary's right to independence. ${ }^{117}$ That guarantee is sometimes secured by financing and sometimes by terms for judicial officers that are not controlled by the government in power. ${ }^{118}$ And in these last few decades, we have seen a willingness of judges to exercise universal jurisdiction, in the sense of using domestic legal power to take jurisdiction over wrongs committed outside a country's borders. ${ }^{19}$ Further, in the spring of 2003 and despite opposition from the United States, the International Criminal Court opened its doors, joining a few other transnational courts. ${ }^{10}$

\footnotetext{
${ }^{114}$ Basic Principles on the Independence of the Judiciary, UN Doc. A/C.ONF.121/22/Rev.1, at 59 (1985), available at <http://wwwl.umn.edu/humanrts/instree/i5bpij.htm>, a declaration adopted at the 1985 Milan Conference and approved by the UN General Assembly, GA Res. 40/32 (Nov. 29, 1985), and 40/146 (Dec. 13, 1985), reprinted in United Nations, Human Rights: A Compilation of International Instruments, v.1 at 386 (1994).

${ }^{115}$ See United Nations Dep't of Pub. Info. DPI/1837/HR (Aug. 1996) (discussing the appointment of Param Cumaraswamy of Malaysia to serve as the Special Rapporteur of the UN Commission on Human Rights and to bring the guidelines on judicial autonomy and the treatment of jurors, lawyers, and prisoners to the fore).

${ }^{116}$ See, e.g., United Nations Office on Drugs \& Crimes, Report of the Third Meeting of the Judicial Group on Strengthening Judicial Integrity (2003), <available at http://www.unodc.org/pdf/crime/ gpacpublications/cicpy.pdf>.
}

\footnotetext{
${ }^{117}$ See, e.g., Open Soc'y Inst., Monitoring the EU Accession Process: Judicial Independence in the EU Accession Process (2001), available at <http://www.eumap.org/reports/2001/judicial>.
}

\begin{abstract}
${ }^{118}$ See, e.g., Reference to the Public Sector Pay Reduction Act, P.E.I., 150 D.L.R. 4th 577, 692-93 (Canada 1997) (holding that the Canadian Charter of Rights and Freedoms required that salaries of provincial court judges be protected from political manipulation); Starrs v. Ruxton, 2000 J.C. 208, 226 (H.C.J. 1999) (interpreting the European Convention on Human Rights provision in Art. 6, para. 1, of rights to public hearings before an independent tribunal, and other materials, to hold that temporary judges on the Sheriff Court of Scotland were not permitted. Cf. Clancy v. Caird, 2000 Sess. Cas. 441 (upholding other judgeships appointed by judges rather than prosecutors).
\end{abstract}

\footnotetext{
${ }^{119}$ See, e.g., R. v. Bow St. Metro. Stipendiary Magistrate \& Others, ex parte Pinochet Ugarte (Amnesty International and others intervening) (No. 3), 1 AC 146 (House of Lords, 1999); Kadic v. Karadzic, 70 F.3d 232 (2d Cir. 1995). See generally, Paul Schiff Berman, The Globalization of Jurisdiction, 151 U. Pa. L. Rev. 311 (2002).

${ }^{120}$ See Rome Statute of the International Criminal Court, July 17, 1998, U.N. Doc. A/CONF. 183/9, available at <http://www.un.org/law/icc/statute/romefra.htm>.
} 
Institutions focused on development have likewise seen law as pivotal to the functioning of markets. ${ }^{121}$ The proponents of adjudication, focused on states and on markets and relying on the personage of the professional judge (sometimes working in conjunction with lay judges or juries and empowered to generate remedies) could well claim victory, as that model of decision making is promoted around the world. ${ }^{122}$

\section{RARIFICATION AND DEVALUATION?}

An alternative reading of the data on "Vanishing Trials"-one premised on an amalgam of other judicial decisions, rules, practices, and attitudes-is also plausible. Below, I detail the anti-trial rhetoric of judges, who have translated those attitudes into doctrine and rules that are supported by statutes. Those provisions demonstrate that consensus exists among many judges and legislators about the desirability of limiting access to high-profile adjudicatory venues. Turning to indicators from the private sector, market enthusiasm for less adjudication is exemplified by the many contracts-such as the one I quoted in this article's introduction-that insist on waiving trial rights as a predicate to agreement. From this perspective, whatever the data on trial migration and mutation, the normative valence of going to trial has changed, as leaders of the bench and bar bemoan the need to take cases to trial.

\section{A. Judicial Hostility to Trial}

Judges routinely register objections to going to trial. As a federal trial judge teaching at a training seminar for judges explained in 1976:

One of the fundamental principles of judicial administration is that, in most cases, the absolute result of a trial is not as high a quality of justice as is the freely negotiated, give a little, take a little settlement. ${ }^{123}$

\footnotetext{
${ }^{129}$ See, e.g., Legal and Judicial Sector Assessment Manual: Issues on Legal and Judicial Reform (provided by the Legal Vice Presidency, World Bank) (July 2002). See generally Maria Dakolias, Legal and Judicial Development: The Role of Civil Society in the Reform Process, 24 Fordham Int'l L.J. S26 (2000).

${ }^{122}$ The shift is sometimes contested on a variety of dimensions. For example, terms like "juridification" and "government by judiciary" are used to flag a concern that democracies should not entrust too many decisions to adjudicatory processes. See generally, Ran Hirschl, The Political Origins of Judicial Empowerment Through Constitutionalization: Lessons from Four Constitutional Revolutions, 25 Law \& Soc. Inquiry 91 (2000). From another perspective, concerns are raised that this proliferation results in an undesirable increase in state control. See Richard Abel, The Contradictions of Informal Justice, in The Politics of Informal Justice, at 267-320 (Richard Abel ed., 1982).

${ }^{129}$ Hubert L. Will, Robert R. Merhige, Jr. \& Alvin B. Rubin, The Role of the Judge in the Settlement Process, 75 F.R.D. 203, 203 (1978). The lectures of all three judges are reproduced; the quoted text comes from Judge Will.
} 
A video made in the 1990 s and provided by the Federal Judicial Center reiterates that message by enabling viewers to watch a judge negotiate the settlement of a pending case (brought by a railroad worker seeking damages under the Federal Employee Liability Act). The participants report on screen their satisfaction with the outcome. $^{124}$

Moreover, the sentiment that "a bad settlement is almost always better than a good trial" is recorded in several published decisions. ${ }^{125}$ Also citable are comments such as in "this case, I could hold my nose and accept the settlement, [because] after all, it is said that a bad settlement is better than a good trial." ${ }^{126}$ Further, judges have underscored the special importance of settlement in class actions. As one judge put it: "There is an overriding public interest in favor of settlement, particularly in class actions that have the well-deserved reputation as being most complex."127 As a consequence, as another federal district judge put it, trials are evidence of "lawyers' failure." ${ }^{128}$ Analyses of judicial decision making in litigated cases also support the view that judges avoid decision making, even when in theory they are required to adjudicate competing claims of right. ${ }^{129}$

Why do some of the people who have the word "trial" in their titles- "trial judges"-become leaders of an anti-trial movement? Some are plainly concerned about cost, time, and the other cases waiting in the queue. But those concerns are longstanding and do not, I believe, suffice to explain all the energy spent in recent years to change doctrine and rules. In addition to these familiar concerns, some judges have become frustrated by inept and overly aggressive lawyering. They believe processes and rules of trial-oriented litigation to be ill suited for some of the disputes they encounter. Further, the disjuncture between the fees of highly paid lawyers and

\footnotetext{
${ }^{124}$ See Videotape: The Settlement of Sechrist v. Burlington Northern: A Videotape for Mediators, No. 2553V/94 (available from the FJC).
${ }^{125}$ See, e.g., Hispanics United v. Village of Addison, 988 F. Supp. 1130, 1149 (N.D. Ill. 1997) (citing In re Warner Communications Sec. Litig., 618 F. Supp. 735, 740 (S.D.N.Y. 1980)). The Warner Communications deci- sion described the phrase as a "familiar axiom." Id.

${ }^{126}$ Strong v. BellSouth Telecomm., Inc., 173 F.R.D. 167, 172 (W.D. La. 1997).

${ }^{127}$ See Access Now, Inc. v. Claire's Stores, Inc., 2002 WL 1162422, at *4 (S.D. Fla. May 7, 2002). A state judge
similarly explained: "Due to their uncertainty, difficulty of proof, and length, and in the interest of judicial
economy, class action damage suits should be settled whenever possible, as soon as possible." Stassi v. Boone,
2003 WL 21436995, at *9 (Tex. Dist. June 6, 2003).

${ }^{123}$ Quoted in Resnik, Trial as Error, supra note 8, at 925.

${ }^{129}$ See Wendy Parker, The Decline of Judicial Decisionmaking: School Desegregation and District Court Judges, 81 No. Carolina L. Rev. 1623 (2003); Mitu Gulat \& C.M.A. McCauliff, On Not Making Law, 61 Law \& Contemp. Probs. 157 (1998). 
the salaries of publicly employed judges increase judicial irritation with the processes, seen by jurists as producing more income for lawyers than social good. Yet others may be influenced by concerns about frivolous filings, too many filings, and unease with jury decision making. ${ }^{130}$ Still others may have found themselves restless in the confines of the public system and intrigued by the growing market for private adjudication, with its plausibly more inventive or expert remedies. ${ }^{131}$

But other judges-including many of those currently in the federal judiciaryhave complaints of a different sort. Hostility to trials for them is a placeholder for a larger negativity toward rights-seeking and public regulation. ${ }^{132}$ The anti-trial movement is a part of a more general effort toward privatization of conflicts in which consensualism (based on contracts) triumphs over regulatory constitutionalism. Declining trial rates reflect the contraction of judicial power through congressional limitations on jurisdiction and on remedies, ${ }^{133}$ and through doctrinal constraints imposed by the Supreme Court on judicial authority to imply causes of action ${ }^{134}$ as well as to craft remedies. ${ }^{135} \mathrm{~A}$ few judges have now begun to dissent, ${ }^{136}$ but their complaints have yet to be heard by the leadership. As one chief judge of a federal district court recently explained: "We are utterly supine in the face of our ever-shrinking

\footnotetext{
${ }^{130}$ See Arthur R. Miller, The Pretrial Rush to Judgment: Are the "Litigation Explosion," "Liability Crisis," and Efficiency Cliches Eroding Our Day in Court and Jury Trial Commitments?, 78 N.Y.U. L. Rev. 982 (2003).

${ }^{131}$ See Dezalay \& Garth, supra note 109 , at 167-70 (describing judges moving from public to private spheres and, when leaving the public sector for the private, conferring legitimacy on private arbitration and mediation services).

${ }^{192}$ See Resnik, Constricting Remedies, supra note 11, at 231-71.

${ }^{133}$ See Antiterrorism and Effective Death Penalty Act of 1996, Pub. L. No. 104-132, 110 Stat. 1214, codified at scattered sections of Titles 8, 15, 18, 22, 28, 40, 42, and 50 of U.S.C.; Prison Litigation Reform Act, Pub. L. 801-810, 104-134 (1996), 110 Stat. 1321, codified at 18 U.S.C. $\$ 3626$ (2000) (also limiting the power to setule cases involving prison conditions).

${ }^{134}$ See, e.g., Correctional Services Corp. v. Malesko, 534 U.S. 61 (2001) (refusing to imply a constitutional cause of action when a federal prisoner is held by a privately run prison); Conzaga Univ. v. Doe, 536 U.S. 273 (2002) (holding that alleged violations of a federal statute protecting student privacy did not give rise to a private action for damages); Alexander v. Sandoval, 532 U.S. 275 (2001) (holding that regulations promulgated pursuant to Title VI were not enforceable by private litigants).

${ }^{135}$ See, e.g., Grupo Mexicano de Desarolla S.A. v. Alliance Bond Fund, Inc., 527 U.S. 308 (1999); Great-West Life Ins. \& Annuity Ins. Co. v. Knudson, 534 U.S. 204 (2002); Missouri v. Jenkins, 515 U.S. 70 (1995). See John Langbein, What ERISA Means by "Equitable": The Supreme Court's Trail of Error in Russell, Mertens, and Great-West, 103 Colum. L. Rev. 1317 (2003).
}

${ }^{136}$ Higginbotham, Do We Still Call Them Trial Courts?, supra note 14; Young, Open Letter to U.S. District Judges, supra note 33 . 
jurisdiction." ${ }^{137}$ Under this formulation, a revision of this Symposium's title would be in order, for the problem is not the "Vanishing Trial" but "Vanishing Rights."

\section{B. Judicial Enforcement of Mandatory Arbitration Clauses}

As judges reconfigure adjudication, the distinctions between their work and that of other "dispute resolution" personnel declines. The rise of the anti-adjudication rhetoric is interwoven with changes in doctrine related to judicial enforcement of ex ante waivers in contracts of the right to trial.

Historically, various trade groups as well as some religious and ethnic communities provided their own dispute resolution processes for conflicts arising inside self-contained communities. ${ }^{138}$ As those agreements began to be formalized into contracts, however, American jurists were unwelcoming, guarding their own monopoly power by refusing to enforce contracts to arbitrate. However, during the 20 th century, legislators and court-based adjudicators shifted their attitudes toward their competitors. In 1925, Congress enacted the Federal Arbitration Act (FAA), recognizing arbitration contracts as enforceable obligations. ${ }^{139}$ But even then, federal courts did not always enforce agreements that were entered ex ante and that waived federal statutory rights of access to courts in favor of arbitration. Judges objected, seeing arbitration as too flexible, too lawless, too informal. They contrasted it with adjudication, praised for its regulatory role in monitoring adherence to national norms. ${ }^{140}$

However, by the last decades of the 20th century, the federal courts had embraced alternatives from both within and without. As is familiar, in the 1980s, the Supreme Court reversed an earlier ruling and enforced an arbitration contract even though federal statutory rights were at stake. ${ }^{141}$ Instead of objecting to the informality of arbitration, the Court praised its flexibility. But the majority not only reassessed the qualities of arbitration, it also revised the valence of adjudication. Instead of insisting on adjudication's character as a uniquely regulatory activity, the majority

\footnotetext{
${ }^{13}$ Young, Open Letter to U.S. District. Judges, supra note 33, at 33.

${ }^{138}$ See Lisa Bernstein, Opting Out of the Legal System: Extralegal Contractual Relations in the Diamond Industry, 21 J. Legal Stud. 115 (1992); Robert C. Ellickson, Order Without Law: How Neighbors Settle Disputes (1991).

${ }^{139}$ See Pub. L. No. 68-401, 43 Stat. 883 (1925), codified as amended at 8 U.S.C. § 1 et. seq. (2000).

${ }^{140}$ See, e.g., Wilko v. Swan, 346 U.S. 427 (1954). See generally, Judith Resnik, Many Doors? Closing Doors? Alternative Dispute Resolution and Adjudication, 10 Ohio St. J. on Disp. Resol. 211 (1995).

${ }^{141}$ See, e.g., Dean Witter Reynolds, Inc. v. Byrd, 470 U.S. 213 (1985); Mitsubishi Motors Corp. v. Soler ChryslerPlymouth, Inc., 473 U.S. 614 (1985).
} 
linked adjudication and arbitration as comparable dispute resolution techniques, all appropriate for the resolution of disputes. ${ }^{142}$

The Court's endorsement of arbitration agreements has some limits. For judicial enforcement of waivers of trial rights, the substitutes provided have to vindicate effectively the relevant statutory rights. Further, courts are to evaluate the question, statute by statute, to learn whether Congress intended to exempt a particular statute from arbitrability. ${ }^{143}$ As of 2004 , the Court has concluded that arbitration waivers could be applied to preclude discrimination claims of employees, ${ }^{144}$ that opponents of arbitration bore the burden of showing that the costs of arbitration made it unusable as a technique to vindicate statutory rights, ${ }^{145}$ and that arbitrators (rather than judges) should at the first instance interpret agreements to consider whether contracts permitted aggregate processing. ${ }^{146}$

Many recent decisions exemplify the federal judicial commitment to arbitration. One comes from litigation ${ }^{147}$ involving employees who sought to recover for allegedly unpaid overtime under the Fair Labor Standards Act (FLSA), a federal statute dating from the 1930s that provided for a group-based litigation process before the Federal Rules of Procedure did. ${ }^{148}$ These employees had signed an arbitration agreement that provided for a one-year statute of limitations (in contrast to the two-year FLSA time period). The agreement also required employees to pay half of the expenses of arbitration, to travel to California to arbitrate, and to pursue all claims individually rather than collectively. ${ }^{149} \mathrm{~A}$ trial judge refused to enforce the contract, but the Eighth Circuit reversed. That court concluded that because the contract provided for arbitrators to interpret it, the federal courts had to cede their jurisdiction, at least for initial interpretations. ${ }^{150}$ In another case, a federal court did not invalidate an employment agreement stipulating that "biblically-based media-

\footnotetext{
${ }^{1+2}$ See Gilmer v. Interstate/Johnson Lane Corp., 500 U.S. 20, 27-29 (1991).

${ }^{143}$ Id, at 26.

${ }^{144}$ Circuit Gity Stores, Inc. v. Adams, 532 U.S. 105 (2001).

${ }^{145}$ Green Tree Fin. Corp.-Alabama v. Randolph, 531 U.S. 79 (2001).

${ }^{146}$ Green Tree Fin. Corp. v. Bazzle, 539 U.S. 444 (2003).

${ }^{147}$ Bailey v. Ameriquest Mortgage Co., 346 F.3d 821 (8th Cir. 2003).

${ }^{1+8}$ See Fair Labor Standards Act, 28 U.S.C. $\$ 216(b)$, enacted in 1937 and modified in 1949, and providing for employees to bring "collective actions." In 1966, the Supreme Court promulgated the revised Rule 23 of the Federal Rules of Civil Procedure that today serves as the major means for aggregate processing.

${ }^{149}$ See Bailey v. Ameriquest Mortgage Co., 2002 WL 100391 *3 (D. Minn. Jan. 23, 2002).

${ }^{150}$ Bailey, 346 F.3d at 823.
} 
tion" was the "sole remedy" for any dispute. ${ }^{151}$ In yet another, the Fifth Circuit ruled that the inability of borrowers to read and to understand arbitration agreements did not render them unenforceable. ${ }^{152}$

This Symposium is focused on the state of knowledge about trials. The doctrinal, rule, and statutory developments that I have sketched above demonstrate the need for substantial research investments in. the many alternatives. In the 1990s, for example, the Institute for Civil Justice was commissioned to gather data on case management. Its reports suggest that some interventions prolonged the time to disposition, thereby not necessarily saving either time or money. ${ }^{153}$ (Testing for improved outcomes is made complex by the difficulty of baselines against which to measure.) Given the proliferation of agreements to arbitrate, understanding more about their internal rules and their impact is also needed.

One set of questions relates to demand. Manufacturers, employers, and service providers are frequently inserting clauses requiring dispute resolution outside of court. Do consumers who anticipate conflict choose among products because of variation in dispute resolution options? ${ }^{154}$ Another set of questions focuses on use. If such programs are faster, cheaper, and more user-friendly than courts, one could expect to see a higher rate of claims than would be filed in courts. But rates of claiming are influenced by many factors, including the presence and absence of lawyers, the ability to pursue claims through and in groups, and the availability of a range of remedies. How many disputes are brought to the various providers? If arbitration programs lower entry barriers significantly and rates of claiming rise, will repeat players, presumed to be self-protective, lose interest in requiring them? Other questions focus on variation in the availability of processes and remedies. For example, what is the impact of limitations on pursuit of class-action or other forms of aggregate relief? And what about regulatory effects? Do such requirements alter the underlying levels of conflict or the quality of products, services, and observance of legal norms?

\footnotetext{
${ }^{151}$ Prescott v. Northlake Christian Sch., 369 F. 3d 491, 493 (5th Cir. 2004) (remanding the case for an evidentiary hearing to enable interpretation of whether the parties sought to expand judicial review beyond that provided by the FAA).

${ }^{152}$ Washington Mut. Fin. Group, LLC v. Bailey, 364 F.3d 260 (5th Cir. 2004),

${ }^{153}$ See James S. Kakalick, Terence Dunworth, Laural A. Hill, Daniel McCaffrey, Marian Oshiro, Nicholas M. Pace \& Mary E. Vaiana, Just, Speedy and Inexpensive? An Evaluation of Case Management under the Civil Justice Reform Act (RAND, ICJ, 1996).

${ }^{154}$ Compare Cook's Pest Control, Inc. v. Rebar, 852 So. 2d 730 (Ala. 2002) (upholding consumers' right to pursue claims in court because they had added an addendum to their service contract when paying that, the Supreme Court of Alabama concluded, when followed by continued service, worked to change the terms and preserved their right to trial).
} 
Discussion about the political economy of data collection on courts demonstrated that knowledge about adjudication is driven by its perceived utility-to document a growing need for more judges, courthouses, and staff, and to support more generally the expansionist project of adjudicatory procedure and legalization. I have sketched the kinds of questions relevant to understanding the import of mandatory arbitration requirements and other dispute resolution obligations to make plain not only that such questions exist but also to raise the issue of whose interests will be served by gathering the data requisite to answering them. Which institutional players have incentives to make data collection a requirement? What organizations or governmental entities will fund the infrastructure to gather information relevant to assessing whether the current embrace of these procedures is justified by the claims made on their behalf, either about the qualities of the processes provided or the propriety of applying the contract model to the form clauses that are increasingly common?

\section{Delegation to Agency Adjudicators and to Agency Employees}

Another doctrinal development is central to the devaluation thesis. Early in the 20th century, life-tenured judges were unwilling to permit Congress to devolve judicial power to non-life-tenured judges; Article III jurists thought it likely unconstitutional and certainly unwise to cede tasks other than those perceived as routine and not quite adjudicatory. ${ }^{155}$ But by the 20th century's end, the life-tenured judiciary had reread Article III to permit devolution of "the judicial power" of the federal courts to scores of non-life-tenured judges. ${ }^{156}$ Those rulings are the predicate to the thousands of federal adjudicatory decisions made by ALJs located in agencies and by magistrate and bankruptcy judges in Article III courts-all actors who lack the constitutionally-prescribed life tenure and salary protection that endow Article III jurists with political and cultural capital.

Further, although the term "judge" has now become attached to many of these decisionmakers, the élan of "the federal judge" has not. Many administrative judges work in cramped spaces, do not have their opinions published, and see few private lawyers. Moreover, these judges are sometimes subjected to efforts by agencies to affect their decisions, and increasingly, agencies are seeking to use employees other than administrative law judges commissioned under the APA to render decisions. ${ }^{157}$

\footnotetext{
${ }^{155}$ See Resnik, Inventing the Federal District Courts, supra note 24, at 925-42.

${ }^{156}$ Id. at $625-43$ (detailing the shift in understanding of the need for life-tenured judges and the doctrinal evolution).

${ }^{157}$ As Jeffrey Lubbers explained, there has been a "drift away from ALJs." Jeffrey S. Lubbers, APA-Adjudication: Is the Quest for Uniformity Faltering?, 10 Admin. L.J. 65, 70-71 (1996). See, e.g., Act of Nov. 29, 1999, Pub. L. No. 106-113, app. C, \$ 124, 113 Stat. 1501A-160 (providing authority for reducing backlog to have
} 
One contemporary example comes from recent efforts by the Attorney General of the United States to treat immigration judges as ordinary employees of the Department of Justice and subject to reorganization and reassignment at his directive. ${ }^{158}$ Another relates to complaints about the process for selection of ALJs, resulting in litigation about unlawful scoring of examinations, ${ }^{159}$ allegations of misuse of the veterans' preference, suspension of appointments of new ALJs, and distress about a growing backlog of undecided SSA cases. The conflict over ALJ selection has in turn increased the pressure to use agency employees other than APA-protected judges to do hearings. ${ }^{160}$

Despite such incursions on judicial independence, life-tenured judges have rarely used their clout as adjudicators or lobbyists to export their material privileges (large and often grand courtrooms, higher salaries, law clerks, and smaller case loads) to those with fewer resources, nor to take on work from their less wellresourced siblings. ${ }^{161}$ Rather, life-tenured judges-including, famously, Chief Justice

Native-American probate decisions made by non-APA judges); Ronnie A. Yoder, The Role of the Administrative Law Judge, 22 J. Nat'l Ass'n of Admin. L. Judges 321 (2002); Ann Marshall Young, Judicial Independence in Administrative Adjudication: Past, Present, and Future, 38 Judges J. 16 (1999).

\footnotetext{
${ }^{158}$ Relying on separation-of-power theory, the Supreme Court had concluded in 1950 that immigration cases were subject to the APA, but Congress reversed that judgment. In 1983, the Department of Justice created an administrative division, separating its hearing offices from the INS, and thereby providing distinctions akin to the APA structure. See Edles, supra note 57, at 810-11.

In 2002, before aspects of the INS became a part of the Department of Homeland Security, the Attorney General proposed reducing the number of immigration judges. See Board of Immigration Appeals: Procedural Reforms to Improve Case Management, 67 Fed. Reg. 7309 (Feb. 19, 2002). That proposal was the subject of controversy, with some arguing it had been prompted by a desire to remove a group of individual judges perceived to be less responsive to the government's approach. See Lisa Getter, Immigration Judges Call for Independent Court, L.A. Times, Jan. 31, 2002, at AI; Dana Marks Keener \& Denise Noonan Slavin, An Independent Immigration Court: An Idea Whose Time Has Come: A Position Paper by the National Association of Immigration Judges (Jan. 2002), available at <http://www.woodrow.org/teachers/esi/2002/ CivilLiberties/Projects/Position/PaperImmigrationJudges.pdf>. See also Lubbers, supra note 157.
}

${ }^{159}$ See Meeker v. Merit Sys. Protection Bd., 319 F.3d 1368 (Fed. Cir. 2003): Bush v. Office of Personnel Mgmt., 315 F.3d 1358 (Fed. Cir. 2003). These cases emerge from a change, in 1996, by the Office of Personnel Management (OPM) in the way that it scored exams given to job applicants for administrative law judgeships and the legality of regulations about when to apply the veterans' preference. ${ }^{160}$ See Stephen Barr, Dispute in Hiring of Administrative Law Judges May Not Be Over, Washington Post, May
22, 2003, at B2 (describing how, because of the litigation, 29 agencies are unable to fill openings); Testimony
of Jo Anne B. Barnhart, Commissioner of Social Security in House Ways \& Means Committee, Oversight
Hearings on the Social Security Administration's Management of the Office of Hearings and Appeals, U.S.
House of Rep., Sept. 25, 2003, 2003 Hearings on the SSA and SSA ALJs, supra note 53. Commissioner
Barnhart stated that it takes 1,153 days, of which 525 were due to backlog, to move through the process of
appeals; id. at. 1 .

${ }^{161}$ See, e.g., Judith S. Kaye, Editorial: Federalism Gone Wild, N.Y. Times, Dec. 13, 1994, at A29 (raising concerns about a proposal of a committee on the federal judiciary suggesting that federal courts be divested of most of their diversity cases). Chief Judge Kaye pointed out that the burden of the additional cases would fall on state courts, already coping with dockets larger than those of the federal courts. 
Warren Burger-have opposed conferring life tenure on these "other" judges and have insisted on maintaining status hierarchies even as they support expansion of the roles and responsibilities of non-life-tenured judges. ${ }^{162}$ Indeed, the leadership of the life-tenured judiciary once opposed the suggestion that administrative hearing officers be given the title of "administrative law judge," and then objected again when magistrates gained the appellation "magistrate judge." 163

\section{From Criticism to Privatization}

A summary is in order of the various claims that support the thesis of a devaluation of adjudicatory procedure and a privatization of dispute resolution processes. A segment of the anti-trial movement is committed to a vision that government is best when it governs least. As courts are one method of regulation, a narrower role for courts helps narrow the role for government more generally. ${ }^{164}$ But courts are not the only method by which to limit government. Efforts aimed at limiting government's enforcement role focus not only on civil processes but also on provisions of many bodies of substantive law-tort, contract, consumer, environmental, civil rights. ${ }^{165}$

Other sources of criticism about adjudication are more specific to trial processes. Some see adjudication as unduly formalistic and therefore as impoverished in its lack of humanity. Such critics object to the dominance of lawyers and to adversary adjudicatory processes-seen as depersonalizing, objectifying, and distancing claimants. ${ }^{166}$ Others view the adversary model itself as a form of "junk

\footnotetext{
${ }^{162}$ See Eric A. Posner, The Political Economy of the Bankruptcy Reform Act of 1978, 96 Mich. L. Rev, 47 (1997).

${ }^{163}$ Resnik, Trial as Error, supra note 8 , at $986-90$.

${ }^{164}$ According to documents from the Department of Justice in the $1980 \mathrm{~s}$, proponents of this vision of government saw courts as critical and tried to shift doctrine; when unsuccessful, they focused on selecting judges who would embrace this viewpoint. See Dawn E. Johnsen, Ronald Reagan and the Rehnquist Court on Congressional Power: Presidential Influences on Constitutional Change, 78 Indiana L.J. 363 (2003) (citing and detailing White House papers setting forth the agenda in the 1980s).
}

${ }^{165}$ See, e.g., The Private Securities Litigation Reform Act of 1995, Pub. L. No. 104-67, 109 Stat. 737, codified at 15 U.S.C. $\$ 77 \mathrm{c}-1$; The Prison Litigation Reform Act, codified in port at 18 U.S.C. $\$ 3626$.

${ }^{166}$ See Jonathan M. Hyman \& Lela P. Love, If Portia Were a Mediator: An Inquiry into Justice in Mediation, 9 Clinical L. Rev. 157 (2002); Carrie Menkel-Meadow, For and Against Settlement: Uses and Abuses of the Mandatory Settlement Conferences, 33 UCLA L. Rev. 485 (1985). See generally, Stephen B. Goldberg, Frank E.A. Sander \& Nancy H. Rogers, Dispute Resolution: Negotiation, Mediation, and Other Processes (4th ed. 2003). But see E. Allan Lind, Robert J. Maccoun, Patricia A. Ebener, William L.F. Felstiner, Deborah R. Hensler, Judith Resnik \& Tom R. Tyler, In the Eye of the Beholder: Tort Litigants' Evaluations of Their Experiences in the Givil Justice System, 24 Law \& Soc'y Rev. 953 (1990) (describing an empirical study of litigants who found both arbitration and adjudication to be dignifying of their concerns and who reported themselves as feeling some control over those processes). 
science, ${ }^{, 167}$ relying on information produced by parties, ignoring or exploiting cognitive biases, and resulting in suspect decisions. Such critics object to disproportionate (if not extravagant) investments of resources that, they argue, yield flawed states of knowledge.

A related objection argues that adjudication (especially in the United States) provides too much by way of opportunities for process, enabling strategic manipulation that works to the detriment of adversaries and the public. ${ }^{168}$ From this vantage point, 20th-century aspirations for lawyer-based production of information are simplistic, superseded, or wrong. Rules for discovery, crafted before photocopying and computers were commonplace, do not respond to the massive amounts of information that could be generated, stored, or hidden but do provide incentives for lawyers to profit, through hourly billing, from overproduction and obfuscation. ${ }^{169}$

These divergent critiques have succeeded in working significant changes in the rules, doctrine, and processes of courts. Markers of the devaluation analysis include changes to the 1938 rules, now substantially amended to direct judges to promote alternative dispute resolution, ${ }^{170}$ statutes authorizing court-annexed arbitration programs, ${ }^{171}$ and mandates to rely on ADR in agencies as well as in courts. ${ }^{172}$ Under this approach, ADR is the "new" civil procedure ${ }^{179}$ as techniques-such as mediation, arbitration; and settlement conferences, which were once termed "extrajudicial"174have become regular features of civil court processes.

Further, not only have trials "vanished" from courts, but the ADR that is flourishing in courts is increasingly oriented toward negotiation. As ADR scholars regu-

\footnotetext{
${ }^{167}$ This term has gained currency as critics claim that allegations by plaintiffs of harms caused by products or substances are based on a lack of high-quality scientific knowledge. See, e.g., Peter Huber, Galileo's Revenge: Junk Science in the Courtroom (1991).

${ }^{165}$ See, e.g., John H. Langbein, The German Advantage in Civil Procedure, 52 U. Chi. L. Rev. 823 (1985).

${ }^{169}$ George B. Shepherd \& Morgan Cloud, Time and Money: Discovery Leads to Hourly Billing, 1999 U. Ill. L. Rev. 91; see also Dennis E. Curtis \& Judith Resnik, Teaching Billing: Metrics of Value in Law Firms and Law Schools, 54 Stan. L. Rev. 1409 (2002).
}

${ }^{170}$ See, e.g., the amendments of 1993 to Fed. R. Civ. P. 16.

${ }^{171}$ See 28 U.S.C. $\$ 651$ et seq. (2000).

${ }^{172}$ See Alternative Dispute Resolution Act of 1998, Pub. L. No. 105-315, 112 Stat. 299 (1998), amending scattered sections of 28 U.S.C.

${ }^{173}$ See Owen M. Fiss \& Judith Resnik, Adjudication and Its Alternatives: An Introduction to Procedure (Foundation Press, 2003).

${ }^{174}$ The word "extrajudicial" was used in 1983, in Fed. R. Civ. P. 16, to refer to such processes. See Fed. R. Civ. P. 16(c)(7) (as amended in 1983). 
larly point out, under that umbrella fall a host of procedures. Some, like arbitration, look more trial-like as they rely on third-party decision making after hearings. Others, like "collaborative divorce," are deliberately far removed, requiring lawyers who participate to commit that, if efforts to forge agreements collapse, those lawyers will not represent their clients in litigation-based proceedings. ${ }^{175}$ Yet within ADR (or DR as some of its proponents prefer, objecting to the adjective "alternative" as a mischaracterization of the norm), one can also see the growing dominance of processes farther afield from trial.

The details of the court-annexed arbitration programs, authorized by statute for certain federal courts, are illustrative. Despite the infrastructure, arbitrations are infrequent. Ten districts (out of 94 federal district courts) have been designated for such programs. As of 2002, however, seven of the 10 were operating programs. ${ }^{176}$ Those programs in turn provided for references to arbitration in an average of under 8 percent of those districts' civil dockets. ${ }^{177}$ The other three "arbitration districts" were no longer providing that process because they had shifted to mediation, joining some 45 other districts relying on ADR/DR activities focused on settlement. ${ }^{178}$

More generally, judges and lawyers celebrate dispute resolution premised on parties' negotiation; the assumption is that parties possess the requisite information and can, at lower costs, obtain appropriate resolutions. Not surprisingly, institutions supporting ADR have proliferated, convening conferences (on topics such as "Court ADR"), proffering services (from firms with names such as "EndDispute" or "JAMS"-

\footnotetext{
${ }^{175}$ Jane Gross, Amiable Unhitching, with a Prod, NY Times, May 20, at F1 (describing such activities in some 35 states and Canada). See Pauline $H$. Tesler, Collaborative Law: Achieving Effective Resolution in Divorce Without Litigation (ABA, 2001). Criticism of the focus on settlement can be found in Penelope Eileen Bryan, "Collaborative Divorce": Meaningful Reform or Another Quick Fix?, 5 Psychol. Pub. Pol'y \& L. 1001 (1999).
}

${ }^{176}$ See Administrative Office of the U.S. Courts, Judicial Business 2002 [hereinafter AO Judicial Business 2002] at 20 (describing the 3,965 civil cases referred to arbitration, from seven of the 10 districts authorized to do so and noting that the amount of referrals rose by 671 cases from 2001). Seven districts (the Northern District of California, the Middle District of Florida, the Western District of Missouri, the Eastern District of New York, the District of New Jersey, the Eastern District Pennsylvania, and the Western District of Oklahoma) accounted for "all new arbitration cases in ten district courts during 2002." Id.

According to staff at the Western District of Missouri, no court-annexed arbitration have occurred since 1998 because of the use of an early neutral evaluation program. Telephone interview, Nov. 21, 2003.

${ }^{177} \mathrm{AO}$ Judicial Business 2002 , supra note 176 , at 56 , tbl. S-12.

\footnotetext{
${ }^{178} \mathrm{AO}$ Judicial Business 2002, supra note 176 , at 20 (" [c]urrenty, 52 percent of the U.S. district courts use federal mediation procedures to settle cases eligible for dispute resolution"). As Deborah Hensler has pointed out, how much of that is what mediators would call "mediation" as contrasted with settlement conferences focused on obtaining dispositions, is a question not yet answered. See Deborah R. Hensler, A Research Agenda: What We Need to Know about Court-Annexed ADR, 6 Disp. Resol. J. 15 (1999). See also Nancy A. Welsh, Making Deals in Court-Connected Mediation: What's Justice Got to Do With It?, 79 Wash. U.L.Q. 787 (2001).
} 
Judicial, Arbitration, \& Mediation Services, Inc.), teaching law school classes, ${ }^{179}$ and shaping model rules. ${ }^{180}$ Yet, as Wayne Brazil explains, equal access to ADR is not currently provided in courts, and obtaining and then maintaining high-quality processes within ADR remains difficult. ${ }^{181}$

The ABA has played an important role in this movement, with a Dispute Resolution Section founded more than a decade ago that mails to its more than 4,000 members a newsletter with a title capturing the enthusiasm: Just Resolutions. ${ }^{182}$ Battles for ADR turf are now emerging, as some groups come forward to accredit ADR providers. For example, in May 2003, the Federal Mediation and Conciliation Service (FMCS), an independent agency created in 1947 with a focus on collective bargaining agreements, proposed an "Access to Neutrals Initiative" to provide a registry of individual dispute resolution providers who have certain qualifications, education, and experience. ${ }^{183}$ As the FMCS explained, the demand from federal and state agencies for ADR providers required that organization to expand its focus. The leadership of the ABA's Dispute Resolution Section responded with skepticism and argued that such a rule would "unnecessarily discriminate against and disqualify many qualified neutrals in the private sector." 184

Whether the devaluation of adjudication extends beyond the United States is not yet clear. In worldwide debates, it is the United States that has argued for limits on juridical processes-most vividly in the context of Guantanamo Bay ${ }^{185}$ and the

\footnotetext{
${ }^{179}$ Several casebooks are now available. See, e.g., Goldberg, Sander, \& Rogers, supra note 166; Katherine Van Wezel Stone, Private Justice: The Law of Alternative Dispute Resolution (2000); Laura J. Cooper, Dennis R. Noland \& Richard A. Bales, ADR in the Workplace (2000).

${ }^{180}$ See, e.g., the Uniform Mediation Act, proposed for adoption by every state by the National Conference of Commissioners on Uniform State Laws. Aug. 2001, available at <http://www.law.upenn.edu/bll/ulc/ mediat/2003finaldraft.htm>.
}

${ }^{181}$ Wayne D. Brazil, Court ADR 25 Years After Pound: Have We Found a Better Way?, 18 Ohio St. J. Disp. on Resol. 93, 114 (2002) (estimating that fewer than half of the civil cases filed have "real access to courtsponsored ADR services").

${ }^{182}$ The Section also puts out Dispute Resolution Magazine, the Section aspires soon to have a membership of 10,000 members. See Richard Chernick, From the Chair: The Dispute Resolution Section Comes of Age, Dispute Resolution Magazine, at 3 (Fall 2003).

${ }^{183}$ See Summary, Federal Mediation and Conciliation Service, 29 C.F.R. $\$ 1480$, 68 Fed. Reg. 23,634 (May 5, 2003).

${ }^{184}$ Just Resolutions, Vol. 9 (2003).

${ }^{185}$ See Rasul v. Bush, 124 S. Ct. 2686 (2004) (reversing Al Odah v. United States, 321 F. 3d 1134.1139 (D.C. Cir. 2003), which had concluded-based on the government's position-that the "privilege of litigation" did not extend to aliens in military custody on the U.S. Naval Base in Cuba). 
International Criminal Court. ${ }^{186}$ Further, proponents of ADR in other countries, such as Australia, have focused on substantive justice and argued for benchmarks of fairness and justice rather than for conciliation and conflict reduction as the only goals. ${ }^{187}$ But interest in ADR is plainly not limited to the United States, ${ }^{188}$ and some developments abroad suggest that adjudication's detractors in the United States may either find co-venturers elsewhere or be able to export at least some of their concerns. Further, as the export metaphor suggests, pressures for change come from market as well as political forces.

One example comes from developments in England and Wales. A 1996 report, "Access to Justice," 189 concluded that the time had come to curb adversarialism by limiting lawyers' options, calling for increased use of ADR, focusing on settlement, and giving greater authority to judges to manage cases. The 1996 report sought to have lawyers "front load work" through requirements that they undertake efforts, before filing, to reach agreements with opponents. ${ }^{190}$ The report urged that judges, in turn, be given managerial powers aimed at having them help make the costs of proceedings "proportionate" to the amounts at stake. ${ }^{191}$ The report also sought to empower judges to police compliance and to sanction misbehavior, in part by having the power to alter the allocation of costs at the dispute's conclusion based on assessments of the reasonableness of positions taken during proceedings. In 1999, new rules became effective in England and Wales that detail preaction procedures and

\footnotetext{
${ }^{186}$ See John R. Bolton, The United States and the International Criminal Court, Remarks at the Aspen Institute, Berlin, (Sept. 16, 2002), available at <http://www.state.gov/t/us/rm/13538.htm>; Kenneth Roth, The Court the U.S. Doesn't Want, 45 NY Rev. of Books (Nov. 19, 1998).

${ }^{187}$ See Hilary Astor \& Christine M. Chinkin, Dispute Resolution in Australia (2d ed. Butterworths, 2002); John Braithwaite, Restorative Justice \& Responsive Regulation (Oxford Press, 2002); National Alternative Dispute Resolution Advisory Council, Issues of Fairness and Justice in Alternative Dispute Resolution: Discussion Paper (Canberra, Nov. 1997).
}

${ }^{188}$ See, e.g., Christian Duve, European ADR: Commission's "Green Paper" Promotes Discussion, Harmonization, Dispute Resolution Magazine at 10 (Summer 2003) (describing the EU's request for analysis by member states of using ADR in civil and commercial disputes).

${ }^{189}$ Harry Woolf, Access to Justice: Final Report to the Lord Chancellor on the Civil Justice System in England and Wales (1996). This report is often referred to as the "Woolf Report" after its author and now the Lord Chief Justice.

${ }^{190} \mathrm{Id}$. at $107-15$.

${ }^{191}$ Id. at 46-47. To do so, the report called for detailed "protocols" (to be developed through bench/bar committees) for different kinds of cases, which in turn would be assigned to "tracks" (with proposed time tables) depending on their anticipated complexity. Id. at 20-71. 
three tracks for disputes, categorized as "small claims," "fast," and "multi-track."192 And there, like here, revisions are also underway to limit access to appeal. ${ }^{193}$

In short, concepts of "rights to sue" have given way to enforcing obligations to use alternatives, many of which do not permit for aggregate processing or require public disclosure of decisions rendered. Through rule changes as well as through training and educational programs, the definition of the "good judge" has became a judge focused on and able to achieve dispositions with as low investments of time as possible. What is judicial (and judicious) is no longer equated with adjudication, with public processes, or, as these shifting attitudes affect the appellate process, with reasoned deliberation. ${ }^{194}$ Courts have embraced the privatization of public processes, the diminution of transparency, and the decline of regulation. If this is the lens through which one understands decades of changes, the declining trial rates that form the shared predicate for this Symposium are evidence of a broader normative phenomenon, the devaluation of adjudicatory processes.

\section{A Public Dimension}

Even with the normative devaluation of trials, courts continue to be venues with publicly accessible processes-in terms of outsiders being permitted to watch and to obtain information about the facts of disputes and their outcomes. Indeed, while the technology that permits the kinds of data compilations requisite to this Symposium is new, the function of courts as sources of public information is not.

Early on, courts served as a place to record and to verify facts. Some time during the 12th century, according to Pollock and Maitland, English law developed the "seisin under a fine," a "final concord levied by the king's court." 195 The "fine"

\footnotetext{
${ }^{192}$ See generally, Adrian Zuckerman, Civil Procedure 422-40 (Butterworths, Lexis/Nexis 2003); Neil Andrews, English Civil Procedure: Fundamentals of the New Civil Justice System 333-95 (Oxford, 2003); Michael Zander, The State of Justice (2000).

\begin{abstract}
${ }^{199}$ In the late 1990s, a committee filed its report on civil appellate procedures in England and, like the Woolf Report, saw the problems as expense, delay, and complexity, and focused on responses to enhance efficiency. The report raised concerns about rising numbers of appeals and too lenient grants of leave for appeal. Opining that there should be "no automatic right of appeal," the report called for a change in culture through court management, the creation of a fast track for certain appeals, extension of the requirement for leave to appeal-all to result in process deemed proportionate to the scope of a given controversy. See Jeffrey Bowman, Review of the Court of Appeals (Civil Division)-Report to the Lord Chancellor (Sept. 1997).
\end{abstract}

${ }^{194}$ See William L. Reynolds \& William M. Richmond, Studying Deck Chairs on the Titanic, 81 Cornell L. Rev.
1290, 1290 (1996) (commenting that in the federal appellate courts, "circuit judges no longer hear argu-
ment or write published opinions in half of the cases appealed to them, and they delegate much of their
work to large numbers of clerks and staff ... supervised to varying degrees by the judges themselves").

${ }^{195}$ Frederick Pollock \& Frederic Maitland, 2 History of English Law 94-97 (1895). 
was, they assert, "in substance a conveyance of land and in form a compromise of the action." ${ }^{196}$ Although in some instances a real dispute existed, Pollock and Maitland believed that in many instances the litigation was a facade, begun only to enable a compromise to be recorded. As they explain, courts were able to create "indisputable evidence of the transaction" in eras when forgeries "were common."197 Further, through fines, parties were bound to perform and had rights against third parties. ${ }^{198}$ Because compromising without permission was an offense and because the king made money from licenses sold to justices, the system of reliance on courts as notaries had utility for public and private sectors. ${ }^{199}$

This public dimension of courts has become embedded in constitutional doctrine, ${ }^{200}$ constitutional and transnational text, ${ }^{201}$ and rules of court. ${ }^{202}$ These rights of public access come in part from rebellion against secretive state processes and in part from purposes both educational and supervisory. ${ }^{203}$ But what constitutes "openness" and the modes by which information is gathered and disseminated have varied across time and place. Before the 20th century, the public gained knowledge via the open doors of courthouses and courtrooms, through the episodic publication and dissemination of opinions, and by personally inspecting papers filed with courts. In the 20th century, with the rise of the newspaper business, the press provided another route. Today's technologies have many times amplified the possibilities. In addition

\footnotetext{
${ }^{196}$ Id. at 94.

${ }^{197}$ Id. See also S.F.C. Milsom, Historical Foundations of the Common Law 181-82 (1981).

${ }^{198}$ Pollock \& Maitland, supra note 195 , at $95-101$.

${ }^{199}$ Id. at $97-99$.

${ }^{200}$ See, e.g., Richmond Newspapers Inc. v. Virginia, 448 U.S. 555 (1980).

${ }^{201}$ See, e.g., Art. I, $\$ 9$, South Carolina Constitution ("All courts shall be public ..."); Art. 1, $\$ 10$ of the Connecticut Constitution ("All courts shall be open..."); Art. 14 of the International Covenant on Civil and Political Rights, supra note 113 ("everyone shall be entitled to a fair and public hearing by a competent, independent and impartial tribunal established by law. ${ }^{n}$ The press and the public may be excluded for limited reasons); European Convention on Human Rights, Art. 6(1) ("Judgment shall be pronounced publicly but the press and public may be excluded from all or part of the trial in the interests of morals, public order or national security in a democratic society, where the interests of juveniles or the protection of the private life of the parties so require, or to the extent strictly necessary in the opinion of the court in special circumstances where publicity would prejudice the interests of justice.").
}

${ }^{202}$ See, e.g., South Carolina Rule of Civil Procedure 41.1 (2003) (entitled "Sealing Documents and Settlement Agreements" and relying on the state's "long history of maintaining open court proceedings and records").

${ }^{200}$ See generally, Judith Resnik, Due Process: A Public Dimension, 39 U. Fla. L. Rev. 405, 405-26 (1987) [hereinafter Resnik, A Public Dimension]. 
to publication of decisions through the web and access to files through electronic databases, some jurisdictions (both inside the United States and beyond) facilitate access through televising some court proceedings. Specifically, television can be found in the courts of New York, ${ }^{204}$ the Supreme Court of Canada, ${ }^{205}$ and the International Criminal Tribunal for the Former Territories of Yugoslavia. ${ }^{206}$

\section{A. Privatizing Processes at the Appellate and Trial Level}

But we should not assume the stability of either the equation of courts with public access or the equation of administrative agencies and private providers with secrecy. In the federal appellate courts, controversies have emerged about whether judges can limit the citation of their opinions, thereby making the judgments unavailable for use as precedent by other litigants. ${ }^{207}$ Published opinions represent under a third

\footnotetext{
${ }^{204}$ See N.Y. Judiciary Law, Vol. 29, $§ 218$ (as amended, 1995) (authorizing the chief judge of the state or a designee to create an experimental program "in which presiding trial judges, in their discretion, may permit. audio-visual coverage of civil and criminal court proceedings, including trials"); 22 NYCRR $\$ 131.1-131.13$ (providing implementing procedures). See generally, New York State Committee to Review Audio-Visual Coverage of Court Proceedings, An Open Courtroom: Cameras in New York Courts (1997) (recommending the use of cameras in courts and providing an overview of usage in other states).
}

\footnotetext{
${ }^{205}$ Supreme Court, not lower court proceedings, are televised. As to the method, most "courtroom proceedings are televised by the Canadian Parliamentary Affairs Channel (CPAC)," available at <http://www.scccsc.gc.ca/faq/faq/index_e.asp\#f7>. See generally, A. Wayne MacKay, Framing the Issues for Cameras in our Courtrooms: Redefining Judicial Dignity and Decorum, 19 Dalhousie L.J. 139 (1996) (exploring whether, under $\S 2(b)$ of the Canadian Charter of Rights, providing for freedom of the press and of expression, electronic media ought to have access to court proceedings).
}

${ }^{206} \mathrm{All}$ proceedings other than deliberations "shall be in public, unless otherwise provided." See Rule 78 (Open Sessions) of the International Criminal Tribunal for the Former Territories of Yugoslavia, available at <http:/www.un.org/icty/legaldoc/index.htms. When needed for protection of victims or witnesses or for reasons of security or justice, the trial chambers may make provisions for private or in camera processes. Id. at Rule 75 (Measures for the Protection of Victims and Witnesses), Rule 79 (Closed Sessions). Full transcripts and, when appropriate, video recordings are made. Id. at Rule 81 (Records of Proceedings and Evidence). The tribunal's working languages are English and French; in addition, the accused has a right to use his or her own language. Id., Rule 3 . Transmission is provided via a weblink, enabling the public (and especially those in the former territories) to see the proceedings; the languages offered include French, English, and Serbo-Croatian. When witnesses or proceedings raise security problems, the screened images are scrambled as may be the voices of wimesses. See the ICTY at a Glance, with a link to the courtrooms, available at <http://www.un.org/icty>.

${ }^{207}$ Richard Arnold, of the Eighth Circuit, helped to bring attention to this issue with his opinion for the Eighth Gircuit in Anastosoff v. United States, 223 F.3d 898 (8th Cir. 2000), vacated as moot, 235 F.3d 1054 (8th Cir. 2000) (en banc).

In 2003, the Advisory Committee on the Federal Rules of Appellate Procedure proposed a new Rule 32.1, that would state "No prohibition or restriction may be imposed upon the citation of judicial opinions, orders, judgments, or other written dispositions that have been designated 'unpublished,' 'not for publication,' 'non-precedential,' 'no precedent,' or the like unless the restriction is generally imposed upon the citation of all judicial opinions, orders, judgments, or other written dispositions." See Proposed Amendment to Fed. R. App. P. 32.1, available at <http://www.uscourts.gov/rules/app0803.pdf.>, approved Apr. 13, 2004. 
of all terminations on the merits. ${ }^{208}$ Further, in many circuits, oral arguments are held only with the permission of the court, and a significant percentage of cases are decided "on the papers. ${ }^{209}$ If neither an argument takes place nor a decision is published, or if decision consists of a notation that a court has summarily affirmed or reversed a judgment, the public has no window into the appellate court process. Moreover, many circuits also have civil appeals management programs (CAMP), in which litigants are required to confer, in the hopes of settlement rather than appeal. ${ }^{210}$

Turning to the trial courts, privatization of court-based litigation is occurring in a variety of ways. As many have written, most of the "action" at the trial level occurs before trial. ${ }^{211}$ The federal rule governing pretrial processes makes no mention of a role for the public in pretrial conferences. ${ }^{212}$ As to documents filed with courts, the Federal Rules once required that all discovery materials be filed unless a court ordered otherwise. ${ }^{213}$ But as amended in 2002, the rules now require the opposite:

In June, the Standing Committee called for more study of the issue. See generally, Penelope Pether, Inequitable Injunctions: The Scandal of Private Judging in the U.S. Courts, 56 Stan. L. Rev. 1435 (2004); Lauren Robel, The Practice of Precedent: Anastasoff, Noncitation Rules, and the Meaning of Precedent in an Interpretative Community, 35 Indiana L. Rev. 399 (2002); Martha J. Dragich, Will the Federal Courts of Appeals Perish If They Do Not Publish? Or Does the Declining Use of Opinions to Explain and to Justify Judicial Decisions Pose a Great Threat?, 44 Am. U. L. Rev. 757 (1995).

${ }^{208}$ See Judith A. McKenna, Laural L. Hooper \& Mary Clark, Case Management Procedures in the Federal Courts of Appeals 21 (Federal Judicial Center, 2000) (citing data, as of 1998, that the national average of opinions published was 28 percent, and in cases where lawyers represented litigations, 38 percent).

${ }^{209}$ Id. at 11-12 (Federal Judicial Center, 2000) (providing data, as of FY 1998, that the national average of cases decided after oral argument by appellate courts was 41 percent, overall). Of cases in which litigants have counsel, the percentage of decisions after oral argument was 57 percent. Id. See also Reynolds \& Richmond, supra note 194 , at 1290-94.

${ }^{210}$ See Irving R. Kaufman, Must Every Appeal Run its Gamut?-The Civil Appeals Management Plan, 95 Yale L.J. 755 (1986); Anthony Partridge \& Allan Lind, A Reevaluation of the Civil Appeals Management Plan (FJC, 1983). Some proponents of the program report that many settlements are achieved as a result. See Mori Irvine, A Look at Mediation, National L.J., Aug 27, 2001, at B10 ("every circuit court of appeals except the Federal Circuit has formally established a settlement program to help parties resolve their cases while pending appeal"). Data on each circuit's practices can be found in McKenna, Hooper \& Clark, supra note 208, at 26-32 (Table 17: Mediation and Conference Programs in the Federal Courts of Appeals).

21'See Stephen Yeazell, The Misunderstood Consequences of Modern Civil Process, 1994 Wis. L. Rev. 631; Resnik, Trial as Error, supra note 8, at 935-37; Judith Resnik, Whose Judgment? Vacating Judgments, Preferences of Settlement, and the Role of Adjudication at the Close of the Twentieth Century, 41 UCLA L. Rev. 1471 (1994); Marc Galanter \& Mia Cahill, "Most Cases Settle": Judicial Promotion and Regulation of Settlements, 46 Stan. L. Rev. 1339 (1994); Kent Syverud \& Samuel Gross, Don't Try: Civil Jury Verdicts in a System Geared to Settlement, 44 UCLA L. Rev. 1 (1996).

${ }^{212}$ Fed. R. Civ. P. 16.

${ }^{213}$ See Fed. R. Giv. P. 5(d), prior to the 2002 amendment. 
that "discovery requests and responses must not be filed until they are used in the proceeding or the court orders filing." 214

How much information is walled off from the public is an empirical question in need of an answer. The District of South Carolina gained attention in 2002 by issuing a local rule against "secret settlements,"215 a practice that was seen as particularly unappealing when used in settlements of cases with obvious third-party effects. The examples frequently cited are cases involving defective tires and sexual abuse. ${ }^{216}$ Members of Congress and the federal judiciary have now focused on the question, ${ }^{217}$ as has the Federal Judicial Center. As FJC researchers detail, ${ }^{218}$ the question of secrecy needs to be unpacked, with specification across different phases in the litigation process. For example, confidentiality orders on discovery do not always result in sealed settlements. The FJC review has, thus far, found relatively infrequent evidence of sealing of settlements but variation among districts. ${ }^{219}$ The appropriate rule is

\footnotetext{
${ }^{214}$ Fed. R. Civ. P. 5(d). Included are depositions, interrogatories, requests for documents and for admissions.

${ }^{215}$ See Adam Liptak, Judges Seek to Ban Secret Settlements in South Carolina, N.Y. Times, Sept. 2, 2002 at A1, A13 (discussing Local Civil Rule 5.03 (D. S. Cal. 2002) prohibiting sealed settlements if filed in courts but not limiting the ability of parties by agreement to "restrict access to documents ... not filed with the Court"). See also Joseph F. Anderson, Jr., Hidden from the Public by Order of the Court: The Case Against Government-Enforced Secrecy, 55 So. Carolina L. Rev. 711 (2004) (explaining how and why the rule was promulgated).

Rules from the state courts of South Carolina also create presumptions against sealing documents but provide for judges to weigh factors in deciding whether to permit sealing. See S.C. R. Civ. P.41.1 (2003) (Sealing Documents and Settlement Agreements). See Jean Hoefer Toal \& Bratton Riley, The New Role of
} Secret Settlements in the South Carolina Justice System, 55 So. Carolina L. Rev. 761 (2004).

${ }^{216}$ See James E. Rooks, Jr., Let the Sun Shine In: "Sunshine" Laws Do Not "Chill" Settlements Say Advocates of Open Courts, 39 Trial 18 (June 3 2003).

${ }^{217}$ See S. 817, Restrictions on Protective Orders and Sealing of Cases and Settlements, 108th Cong., 1st Sess (Apr. 8, 2003); the exchange of letters between Senator Herb Kohl and L. Ralph Mecham, Director of the Administrative Office of the U.S. Courts, Sept. 18, 2002 and Oct. 3, 2002 (discussing the Advisory Committee on Civil Rules' opposition to legislation that would have required judges to make particularized findings of fact before approving any protective order involving discovery).

\footnotetext{
${ }^{218} \mathrm{FJC}$ researchers found that about half of the district courts had local rules addressing sealing of documents and that some detailed the grounds and duration of sealing while others addressed the mechanics of sealing. See Tim Reagan, Marie Leary, Shannon Wheatman, Tim Willging, Natacha Blain, George Cort \& Dean Miletich, Sealed Settlement Agreements in Federal District Courts-May 2003 Progress Report at 2-3 (Federal Judicial Center, 2003).

${ }^{219}$ In a September progress report, the researchers noted that the practice of keeping agreements confidential was common, but that determining what documents were sealed was more difficult. See Tim Reagan, Shannon Wheatman, Marie Leary, Natacha Blain, Steve Bensler, George Cort \& Dean Miletich, Sealed Settlement Agreements in Federal District Court: Research Progress Report as of September 8, 2003. After a review of 128,888 civil cases filed in 29 districts, the researchers found relatively few sealed setulements in court dockets, specifically in 300 cases, with none in some districts and more in others. Id. at 4 .
} 
another area deserving of attention. Proponents of privacy in courts argue that more confidentiality, not less, is needed. ${ }^{220}$

\section{B. Public Access to ADR?}

Another issue is access to court-based ADR. My preliminary conclusion from the sources readily available is that the public does not have easy means by which to watch processes or learn about decision making in alternative dispute resolution programs provided by federal courts. Through a recent survey of rules and practices of the seven district courts listed by the Administrative Office of the U.S. Courts as providing court-annexed arbitration, ${ }^{221}$ Andrew Goldstein and I learned that little public information exists about these proceedings. Most of the local rules do not address the question of whether the public has a right to be present at court-annexed arbitrations. Indeed, not all local rules specify where court-annexed arbitrations are to take place. ${ }^{222}$ In response to our phone calls, staff at clerks' offices explained that court-annexed arbitrations occur in courtrooms if space exists or at an offsite neutral location, such as an arbitrator's office. ${ }^{223}$ As to whether nonparticipants could be present, the deputy clerk of one district informed us that the proceedings are private. ${ }^{224}$ In another district, where the local rule provides for the arbitration hearing

As to whether any of those cases have third-party consequences, researchers focused on two sets of claimsthose filed under the Fair Labor Standards Act (FLSA), which can by statute involve group relief for failure to pay overtime, and those filed as class actions. Of the cases sealed, 18 percent were FLSA cases and 11 percent were class actions. Id. at 7 . In addition, the FJC progress report identified certain kinds of cases (product liability and abuse) as instances of "special public interest" and found examples of sealing in more than 100 cases, so defined. Id. at 9 .

${ }^{220}$ See, e.g., Stephen E. Darling, Confidential Settlements: The Defense Perspective in Symposium CourtEnforced Secrecy: Formation, Debate, and Application of South Carolina's New Secrecy Rules, 55 S. Carolina L. Rev. 785 (2004). See generally, Arthur R. Miller, Confidentiality, Protective Orders, and Public Access to the Courts, 105 Harv. L. Rev. 427 (1991); Richard K, Marcus, The Discovery Confidentiality Controversy, 1991 U. Ill. L. Rev. 457.

${ }^{221}$ Specifically, the districts listed by the $\mathrm{AO}$ as providing court-annexed arbitration are the Northern District of California, the Middle District of Florida, the District of New Jersey, the Eastern District of New York, the Western District of Missouri, the Eastern District of Pennsylvania, and the Western District of Oklahoma. See Administrative Office of the U.S. Courts, 2002 Annual Report of the Director: Judicial Business of the U.S. Courts, tbl. S-12 (2003).

${ }^{222}$ See, e.g., Local Rule 16.5, Alternative Dispute Resolution, Western District of Missouri, adopted Sept. 20, 2003 (describing the use of neutral third parties to resolve controversies but providing no details as to the place in which such processes occur). Compare Local Rule 201.1(f), District of New Jersey (with revisions as of Oct. 6, 2003) (providing that a court order specify the time and place of the arbitration).

${ }^{223}$ See, e.g., ADR Local Rule 4-5, Northern District of California (providing that arbitrations could be held anywhere within the physical boundaries of that district).

${ }^{224}$ Telephone interview, Nov. 14, 2003, with the Deputy Clerk, District of New Jersey. 
to take place in a room in the courthouse,${ }^{225}$ a clerk explained that nonparties could attend only on the consent of the parties and the arbitrator. ${ }^{226}$ In contrast, in the Eastern District of Pennsylvania, court-annexed arbitrations are part of the court calendar, take place in the courthouse, and are open to the public. ${ }^{227}$

As the variety of rules and customs surrounding court-annexed arbitration suggest, even as judges and other dispute resolution providers move away from trials and focus on pretrial management and dispute resolution in chambers and conference rooms, it is possible to build in a place for the public or to wall off proceedings from the public. The scant record we excavated on court-annexed arbitration indicates that it is plausible to permit observation of some proceedings, but to do so requires direction from judges and new rules of court. Thus far, we have found little evidence of debate on the issue, whereas more attention is being paid to the question of public access to settlements achieved through courts.

States have been in the forefront in the United States of legislation that insists on public access to settlements. In 1990, Florida enacted what it entitled the Sunshine in Litigation Act, prohibiting courts from entering an order

which has the purpose or effect of concealing a public hazard or any information concerning a public hazard nor shall the court enter an order or judgment which has the purpose or effect of concealing any information which may be useful to members of the public in protecting themselves from injury which may result from the public hazard. ${ }^{228}$

In 1999, Florida also required that its Department of Public Health publish on the Internet payment of malpractice claims in excess of a specified amount. ${ }^{229}$ At least 20 states have statutes or court rules constraining in various ways the ability to make court documents and outcomes unavailable. ${ }^{230}$ Further, some states have affirmative

\footnotetext{
${ }^{225}$ See Local Civil Rule 83.10(f), Eastern District of New York.

${ }^{226}$ Telephone conversation of Nov. 14, 2003, with a deputy clerk in the Eastern District of New York.

${ }^{227}$ Telephone interview, Nov. 14, 2003. See also Eastern District of Pennsylvania, Local Rules 53.2 (Arbitration: The Speedy Civil Trial"); 53.2(5) ("Arbitration Trial" ... "The trial shall take place in the United States Courthouse in a room assigned by the arbitration clerk.").
}

${ }^{228}$ Fla. Stat. Ann. $\$ 69.081$ (2002).

${ }^{229}$ See Fla. Stat. Ann. $\$ 456.041$ (4) (1999), as amended Sept. 15, 2003 (now requiring reporting from certain kinds of doctors of payments of claims that exceed $\$ 100,000$ ).

${ }^{230}$ Included on that list are Arkansas, Arizona, California, Delaware, Florida, Georgia, Hawaii, Idaho, Indiana, Kentucky, Louisiana, Massachusetts, Michigan, Nevada, New Jersey, New York, North Carolina, Oregon, South Carolina, Texas, Virginia, and Washington. Coverage and exceptions vary widely. See, e.g., Ark. Code. Ann. $\$ \S 16.55-122,25-18-401$ (Michie. Supp., 2001) (prohibiting the sealing of government documents and voiding private contracts that limit disclosure of environmental hazards); N.C. Gen. Stat. \$ 132-1.3 (2002) (prohibiting sealing of settlements of "any suit, administrative proceeding or arbitration instituted against any agency of North Carolina government or its subdivisions" arising out of government actions except 
obligations to provide information about health-care professionals to the public. ${ }^{231}$ Parallel federal legislation (also called the Sunshine in Litigation Act) has been proposed but not enacted ${ }^{232}$ but, as noted, one district court has created a "sunshine" provision through local rule making. ${ }^{233}$ As I write, however, some of these provisions are being contested as violating state and federal rights to privacy.

As I hope this discussion has made plain, public access to and information about dispute resolution have historically been achieved through locating those processes inside courthouses. Until the invention of the pretrial process, judges formally encountered lawyers in open courtrooms, where nonparties could watch the proceedings. As long as courts continue to be places that produce public data in volume and kind outstripping that produced about adjudication in administrative agencies, and as long as private providers do not regularly disseminate information about or provide access to their processes, then with the declining trial rate comes a diminution of public knowledge of disputes, of the behavior of judges, ${ }^{234}$ and of the forging, in public, of normative responses to discord..$^{235}$

The questions become whether to accept privatization of process or to engraft a public dimension on pretrial processes onto ADR in courts, as well as onto adjudication and ADR in agencies. Also at issue is what, if any, demands for public information ought to be made of private dispute resolution providers. One aspect of the problem focuses on process: What role does an audience have in the activities of

related to medical care involving hospitals unless the policy of openness is overridden and no other less restrictive means is available); Wash. Rev. Code Arin. $\$ 18.71 .350$ (West, 1999) (requiring professional liability insurers of physicians to report settlements in excess of $\$ 20,000$ or the payment of three or more claims within a five-year period), $\S 4.24 .611$ (limiting confidentiality provisions when claims relate to product liability or hazardous substances).

${ }^{23}$ See, e.g., New Jersey Health Care Consumer Information Act, N.J.S.A. 45:9-22.21 et seq., enacted in June 2003, requiring that all "medical malpractice court judgments and all medical malpractice arbitration awards" in which a complaining party had received an award within the five most recent years be made available to the public in profiles of physicians and podiatrists licensed to practice in the State of New Jersey. In May 2004, a few weeks before the Act was to become effective, the Medical Society of New Jersey sued the State's Consumer Division to enjoin implementation of the Act, argued to be in conflict with federal rights of expectations privacy under 42 U.S.C. $\$ 11137$ and the U.S. Constitution. See Malpractice Data Blocked, N.Y. Times, May 10, 2004 at B4; Medical Society of New Jersey v. State of New Jersey et al., CV 04-2126 (filed May 6. 2004).

${ }^{232}$ Sunshine in Litigation Act of 2003, S. 817, 108th Cong., 1st Sess (2003). Earlier comparable bills were introduced in 1999, 1995, and 1993.

${ }^{233}$ See supra note 215 (discussing the local rule in the District for South Carolina).

${ }^{234}$ English case law sometimes relies on Bentham's rationale: "Publicity is the very soul of justice. . . . It keeps the judge himself, while trying, on trial." See Andrews, English Civil Procedure, supra note 192, at 79-81 (citing Select Extracts of the Work of Jeremy Bentham 115 (1943)).

${ }^{255}$ See Resnik, Due Process: A Public Dimension, supra note 203, at 427-31. 
dispute resolution other than trial? Another aspect is focused on outcomes: What information, either individualized or in the aggregate, is available to the public?

Here I want to underscore the conceptual possibility that courts could be reinvented as institutions of settlement but nonetheless be required to enable forms of public access and participation. Options range from letting outsiders into ADR/DR to watch (as court or agency "observers") to mandating forms of databasing that would permit either individual or aggregate knowledge about processes and outcomes in public and in private settings. As to the source of rules-legislative, court made, or developed through doctrine-judges today have their typical default role of law making when statutes and rules are silent. Judges are now actively involved in shaping a "law of settlement," sometimes promoting and other times damping down access rights. For example, in the context of debates about whether, at parties' behest, courts should vacate judgments, ${ }^{236}$ debate occurs about whether to understand judge and jury decision making as a public or private good, protected or destructed by public or private decision making. Another facet of public access has emerged in the discussion of rights of public and judicial access to "side settlements" among participants in class actions. ${ }^{237}$

In short, just as pretrial processes and court-connected ADR have been invented through rules of court, so could courts impose rules and shape incentives on nonadjudicatory resolutions. Further, as the current crop of contracts for arbitration demonstrates, courts also have a good deal of control over the forms that the market for noncourt-based resolution takes. To make such rules and shape practices to enhance public access (e.g., by requiring inclusion of data reporting or preclusion of secrecy) requires a normative recommitment to the importance of public access coupled with the development of new rules and institutional infrastructures equipped to produce and to gather the data. ${ }^{238}$ Those decisions rest, in part, on positions taken by the leadership of the legal profession.

\section{TOO FEW Trials or TOO MANY COURTROOMS? THE DISTRIBUTION OF JUDICIAL RESOURCES}

Part of the purpose of this Symposium is to consider the future. The federal judiciary remains in a dominant position to affect the shape of adjudication in the United

\footnotetext{
${ }^{236}$ See, e.g., Neary v. Regents of Cal., 3 Cal. 4th 273 (1992).

${ }^{237}$ See, e.g., Amchem Prods. Inc. v. Windsor, 521 U.S. 591 (1997).

${ }^{238}$ Wayne Brazil, in contrast, has concerns about the minimal equipage provided to courts for their ADR programs. See Wayne D. Brazil, Comparing Structures for the Delivery of ADR Services by Courts: Critical Values and Concerns, 14 Ohio St. J. Disp. Resol. 3 (1999). For efforts to help share information about access, see SJI Guidelines for Public Access to Court Records: A National Project to Assist State Courts, 13 SJI News 2-3 (Fall 2002).
} 
States, but its position has complexities not yet addressed. The federal judiciary's stature rose with the positive political significance attached to adjudication. Even as the federal judiciary's leadership has been a significant source of the normative devaluation of adjudication, some within have begun to understand the potential vulnerability occasioned by the waning of its monopoly on dispute resolution.

About a decade ago, Bryant Garth identified the risk that, given the expansion of the private market in adjudications, publicly-funded judges would lose what they saw as the "good cases" (interesting legal issues, well presented through resourced litigants). ${ }^{239}$ Important constituencies could leave the public sector in favor of the private. Parallels can be found in the increased roles that private education and private policing are playing in communities around the United States. As William Young recently put it, "ominously, for the first time in our history, business has a good chance of opting out of the legal system altogether."240

The convening of the events around "The Vanishing Trial" project is itself evidence that the bar's leadership may now be worried about the prospect of too much success of its own anti-adjudicatory positions-that trials are at risk of becoming an endangered species. To pursue the metaphor, the loss of trials also brings risks to its habitat. Concern that declining trial rates may portend declining funding of the judiciary and the provision of fewer courtrooms can be found in the text of recent statistical reports from the federal judiciary, insistent on explaining that, despite declining trials, demands for and on judges - working in courtrooms of their own-remain high.

For example, in its 2002 annual statistical report, ${ }^{241}$ the $\mathrm{AO}$ devotes several paragraphs to the topic of "trials completed." 242 Those paragraphs address dropping trial rates ${ }^{243}$ give the specific numbers of civil and criminal trials as well as data on percentage decreases, ${ }^{244}$ and then provide a good deal of explanation. To buffer federal judges from accusations that, without trials, they have less to do and less need

\footnotetext{
${ }^{299}$ Bryant G. Garth, From Civil litigation to Private Justice: Legal Practice at War with the Profession and its Values, 59 Brooklyn L. Rev. 931 (1993). See also Dezalay \& Garth, supra note 109, at 154-72 (describing the "breaking of the monopoly" of courts).

${ }^{240}$ Young, Open Letter to U.S. District Judges, supra note 33, at 33.

${ }^{241} \mathrm{AO}$ Judicial Business 2002, supra note 176 . These reports began to address declining trial rates in 1998, which was also a year in which civil filings declined (for the first time in five years) by about 6 percent while terminations rose by 5 percent. See Administrative Office of the U.S. Courts, Annual Report of the Director: Judicial Business of the United State 1998 at tbl. S-7, tbl. C (1999). Each report thereafter has paragraphs addressing the declining trial rates. See notes $243-51$, infra.

${ }^{242} \mathrm{AO}$ Judicial Business 2002, supra note 176, at 23-24.

${ }^{243}$ Id. at 23 ("Total civil trials decreased 8 percent (down 498) nationally, with fewer trials reported in 63 districts. ... Forty-four districts reported decrease in criminal nonjury trials.").

${ }^{244}$ Id. at 23 (stating that "the number of civil and criminal trials completed in the U.S. district courts by Article III judges decreased 5 percent: 12,81 7 cases were resolved by trial. . . . Total criminal trials dropped 3 percent nationwide (down 243) to $6,802^{\prime \prime}$ ).
} 
for their own courtrooms, the AO states: "These decreases reflect the changing nature of case disposition in the district courts. Despite fewer trials, judges remain active in managing and disposing of their cases." 245 The 2002 report emphasized that 82 percent (or 212,838) of the dispositions in civil cases occurred "before or during pre-trial proceedings," ${ }^{246}$ and also noted that that figure ( 82 percent) has remained stable over the last six years. ${ }^{247}$ Moreover, the AO argues:

[i]n addition to research and opinion drafting, many case-related events not classified as "trials"-such as hearings on motions for summary judgment and other dispositive motions, hearings on sentencing issues, Daubert hearings on expert witnesses, evidentiary hearings in pro se prisoner and other cases, supervised release and probation revocation hearings, and activities related to alternative dispute resolution (ADR) and settlementsinvolve substantial judicial activity. ${ }^{248}$

Comparable discussions appear in the 2001 report $^{249}$ and in the 2000 report, ${ }^{250}$ both emphasizing that much of what judges did took place "in the courtroom." 251

${ }^{245}$ Id. at 23.

${ }^{246} I d$.

${ }^{247}$ Id. As the data in "The Vanishing Trial" detail, the percentage of cases that used to terminate "with no court action" has declined. Whether judges actually invest much time in cases terminated "before or during pre-trial proceedings" is one question; whether that time is a wise investment (in terms of either the quality or quantity of dispositions) is yet another.

${ }^{248} \mathrm{AO}$ Judicial Business Report 2002, supra note 176, at 23-24. The AO also noted that the "reasons for fewer trials are numerous" and citing increased use of $\mathrm{ADR}$, the costs of trial and risk of sanctions on the criminal side, and the fact that the decline is part of a "longer-term phenomenon." Id. at 24.

${ }^{249}$ Administrative Office of the U.S. Courts, Annual Report of the Director: Judicial Business 2001 at 25 . The report states that the

trends reflect the changing nature of case disposition in the federal district courts. Large numbers of cases resolved by court action before trial-including those disposed of by summary judgment, dismissal, or consent judgment-remain a major factor in the overall reduction in total civil trials this year. The implementation of alternative dispute resolution (ADR) programs in the district courts also likely has contributed to the termination of more cases without trial on the merits. ADR programs involving mediation and arbitration are currently active in 41 districts. Other possible factors include the increasing use, and judicial enforcement, of compulsory arbitration clauses in employment and other contracts. ... Judges in the district courts remain active in managing and disposing of their cases.

The report also mentions that magistrate judges presided at 10,663 trials in 2001 .

${ }^{250}$ Administrative Office of the U.S. Courts, Annual Report of the Director: Judicial Business 2000 at 23-26. After a discussion of trends, the report states that the "overall reduction in total trials in 2000 was offset by the impact of the multiple types of judicial proceedings included in the caseload of federal judges. Many nontrial events required significant amounts of judges' time, often in the courtroom." Id. at 25.

${ }^{251} \mathrm{AO}$ Judicial Business 2001, supra note 249, at 25 ("Many case events not classified as 'trials' require significant amounts of judges' time, typically in the courtroom."). See also 2000 AO Report, supra note 250 , at 25. 
The $\mathrm{AO}$ is quite right to worry, for it represents the federal judiciary in Congress and has to make the case for new courthouse construction, new judgeships, and budgets. During the last several years, members of Congress have repeatedly questioned the practice that federal judges always need courtrooms of their own. ${ }^{252}$ Such inquiries have led to a series of federal studies by the General Accounting Office (GAO). Its 1997 analysis concluded that federal courtrooms were used (defined as "lights-on" for any event, from trials to "events [that] lasted less than an hour") ${ }^{253}$ about 54 percent of the time. ${ }^{254}$ Yet the federal judiciary's leadership has remained committed to individual courtrooms, produced through new construction and through renovations. The argument is that each judge's access to an available courtroom makes for better and more efficient justice. ${ }^{255}$ Reflective of that view is a current 45-project construction proposal (for 2002-2006), projected to cost $\$ 2.6$ billion. $^{256}$ Each courtroom, with its adjacent office space, is estimated as costing some $\$ 1.5$ million..$^{257}$

The back and forth between Congress and the judiciary on this issue have produced several reports. A commissioned Ernst and Young Study came under fire from the GAO, which described the Ernst and Young report as flawed because it was based on a mathematical formula of questionable validity (lacking "data, rationale, or ana-

\footnotetext{
${ }^{252}$ See Conference Report 106-1005, to Accompany H.R. 4942, Making Appropriations for the Government of the District of Columbia and Other Activities, U.S. House of Rep. 106th Cong., 2d Sess. at 287-88 (Oct. 25,2000 ) ("any reduction in the number of courtrooms and associated court space could significantly reduce rental payments, which continue to consume an inordinate amount of the Judiciary's available resources"). Rent is paid to the GSA, which is the owner of courthouses. See Hearings on Leases, Courthouse Construction and the 1999 Capital Improvement Programs before the Subcomm. on Transportation and Infrastructure, Committee on Environment and Public Works, U.S. Senate, Sept. 17 1998), 1998 WL 640299 at *2 (statement of Robert A. Peck).
}

\begin{abstract}
${ }^{253}$ That description comes from a 2000 GAO report, impatient with the use of that 54 percent figure by Ernst and Young to support the thesis that each judge needs a courtroom of his or her own. See General Accounting Office, Courthouse Construction: Sufficient Data and Analysis Would Help Resolve the Courtroom-Sharing Issue GAO-01-70, at 8, 18 (Dec. 2000) [hereinafter GAO Courthouse Construction $2000]$.
\end{abstract}

${ }^{254}$ See General Accounting Office, Courtroom Construction: Better Courtrooms Use Data Could Enhance Facility Planning and Decisionmaking GAO/GGD-97-39, at 2-3 (1997).

${ }^{255}$ See, e.g., Comments from the Chair, Judicial Conference, Committee on Security and Facilities, Oct. 31 2000, appended at 57 to the GAO Courtroom Construction 2000, supra note 253 (underscoring the "value of unfettered access to a courtroom and its importance to the fair and efficient administration of justice").

${ }^{256}$ General Accounting Office, GAO-02-341, Courthouse Construction: Information on Courtroom Sharing (2002).

${ }^{257}$ Id. at 3, n. 3. 
lytical basis") and incorrectly used earlier data. ${ }^{258}$ Another study, from the Congressional Budget Office, modeled a reduction in courtroom space while keeping trial rates at their 1995 levels and concluded that fewer courtrooms would result in small delays but courtrooms would continue to be unused about 40 percent of the time. ${ }^{259}$ The judiciary responded by eliciting policy statements from each of the federal circuits about the plausibility of courtroom sharing, by raising the possibility that senior or visiting judges might share courtrooms, and, in a few instances, by judges sharing courtrooms. ${ }^{260}$

The AO properly understands that the shift in the nature and kind of work of judges prompt the question of the need for the significant buildings now under contract. If judges are in the business of settling cases, they do not necessarily need courtrooms in which to work. In the FJC's educational video on settlement, ${ }^{261}$ for example, discussions took place at a conference table around which the parties, their lawyers, and the judge sat. Moreover, some judges go further in urging informality as a lubricant to settlement. At one seminar teaching judges about settlement, a jurist described how, to help facilitate communications in a complex case, he had invited all the lawyers over to his home. ${ }^{262}$

Thus the declining trial rates and the move toward informal process do not fit easily within the "ambitious" federal judicial program of courthouse construction underway or recently completed. ${ }^{263}$ Those efforts, prompted by concern in the early 1990 s of a "crisis" related to space for a growing judiciary, ${ }^{264}$ have produced architecturally important buildings, appointed with public art as required by federal art-

${ }^{258} \mathrm{GAO}$ Courthouse Construction 2000 , supra note 253, at 8, 16. Ernst and Young concluded that courtroom sharing would not be feasible in districts with fewer than five courtrooms and would result in serious scheduling problems in places with six to ten courtrooms. Id. at 11. The GAO commented that 91 percent of the courthouses fall within the category of five or fewer courtrooms. But, "about 40 percent of all current, active district judges are located in the remaining 9 percent of the courtrooms." Id. at 19.

${ }^{259}$ Congressional Budget Office, The One Courtroom, One-Judge Policy: A Preliminary Review 12 (Apr. 2000).

${ }^{260} \mathrm{GAO}$ Courthouse Construction 2002, supra note 253 , at 21-39.

${ }^{261}$ See note 124 supra (discussing the videotape for mediators).

${ }^{262}$ Will, Merhige \& Rubin, supra note 123, 75 F.R.D. at 212-13.

${ }^{269}$ See Heidi Landecker, Federal Architecture: A New Era, 85 Architecture 64, app. at 76-78 (describing some of the 156 building projects, including renovations). In 2004, the Judiciary pursued funding by going directly to Congress, which appropriated $\$ 205$ million for nine new courthouse and $\$ 17$ million for office buildings and repairs. See Courthouse Funding Squeezes Through in Final Conference, 36 Third Branch 4 (Feb. 2004).

${ }^{264}$ See GSA Properties, Courthouse Programs (describing the concern about space, the need for "the largest courthouse construction program in more than fifty years, estimated to cost $\$ 10$ billion," and the establishment by the Judiciary of a list of priorities), available at <htp://www.gsa.gov/Portal/gsa/ep/contentView. Do?contentType+GSA_OVERVIEW>. 
in-architecture regulations. ${ }^{265}$ The openings have been greeted with the fanfare appropriate to the commitment of resources they represent. For example, in the fall of 1998, I participated in another symposium, held in conjunction with the opening of the courthouse constructed in Boston for the District of Massachusetts and the First Circuit Court of Appeals. ${ }^{266}$ That court, designed by architect Harry Cobb, with paintings by Ellsworth Kelly, is a 10-story building with a huge conoid of glass that forms one wall of the courthouse and that dominates the public space by permitting views of the floors above. ${ }^{267}$ Upon entering, one can see more than two dozen arches, each marking the entry to a courtroom. Twenty-five of those courtrooms are for the trial court. ${ }^{268}$ In each, a judge's bench is on the back wall, a bit lower than is common, in a self-conscious effort to portray law as accessible. ${ }^{269}$

The designers chose the arches and the courtrooms as central icons of their building. ${ }^{270}$ But consider the trial rate of the federal district courts. In the District of

\footnotetext{
${ }^{265}$ See General Services Administration, Rules and Regulations, Final Rule, Real Property Policies, 66 Fed. Reg. 5358 (Jan. 18, 2001) (describing the policies); 41 C.F.R. $\$ \$ 102-107.10(f)$ (describing the GSA's policy divisions, including art in architecture); 102.77 .10 (indicating that federal agencies "must incorporate fine art as an integral part of the total building concept when designing new Federal buildings and when making substantial repairs and alterations to existing Federal buildings, as appropriate. The selected fine arts, including painting, sculpture, and artistic work in other media, must reflect the national cultural heritage and emphasize the work of living American artists"); 102-77.15 (requiring funding, if not prohibited by law, by "allocating a portion of the estimated cost" of construction); 102.77.20 (requiring agencies to seek "support and involvement of local citizens" and collaboration with architects when selecting artwork). The GSA allocates one-half of 1 percent of buildings' construction budgets and maintains a registry of slides of artists hoping to obtain commissions. See GSA, Design Excellence and the Arts, available at <http://www.gsa.gov/Portal/gsa/ep/programView.do?programId=8278>.
}

${ }^{266}$ See Symposium, Art and Architecture of Civil Buildings: A Symposium to Celebrate the Opening of the United States Courthouse (Sept. 24, 1998) Boston, MA (presentation by Dennis E. Curtis \& Judith Resnik, program on file with the author).

${ }^{267}$ See Douglas P. Woodlock, Architecture and the Design of the New Federal Courthouse in Boston (Lecture for the Boston Society of Architects 1994-1995 Lecture Series, Jan. 25, 1995) at 22, 25-26 (manuscript on file with the author) [hereinafter Woodlock, The New Federal Courthouse in Boston].

${ }^{268} \mathrm{Six}$ are for magistrate judges, whose courtrooms are somewhat smaller than those of district judges. See US Courts Design Guide 4-41 (Dec. 19, 1997).

\footnotetext{
${ }^{269}$ See Woodlock, The New Federal Courthouse in Boston, supra note 267, at 28-29. The witness box sits in front of another wall, the jury box in front of another, and the public in fixed benches along the fourth wall. Each wall has its own arch of equal height to suggest the equality of all participants before the law.

${ }^{270}$ As one of the judges active in the planning explained, a design challenge was how to construct a building that "affirm[ed] the singular importance of the courtroom when multiplying the number of spaces claiming that name and yet diminishing the portion of the building devoted to that space." Id. at 18 . The building's architect Harry Cobb noted that the "whole enterprise [of courthouse construction] is devalued by being wrapped by hundreds of thousands of square feet of bureaucratic space." Ziva Freiman, Shoring up the Center, Progressive Architecture, at 84, 88 (Apr. 1993); see also Landecker, supra note 263, at 67 ("Architects are struggling to build courthouses without devaluing the individual courtroom.").
} 
Massachusetts in 1998, when the new courthouse opened, about four civil cases out of 100 completed a trial. ${ }^{271}$ Including criminal trials, about 180 trials (bench or jury) were held in 1998, or no more than about seven per courtroom. ${ }^{272}$ of course, as the $\mathrm{AO}$ has noted, a range of activities occur in courtrooms other than trials, so courtrooms' "lights" are on more of the time. ${ }^{279}$ But the Local Rules of the District of Massachusetts insist that, at every meeting with lawyers, judges promote disposition of cases by "settlement or other alternative dispute resolution programs." ${ }^{274}$ Yet the symbols central to the 1998 building are the exterior and interior arches of courtrooms, organized not as multifunction spaces easily convertible from courtrooms to conference rooms, but as if juries and judges were therein regularly rendering judgments on disputed questions of law and fact.

New courthouse construction in other districts follows a similar pattern-with large and impressive buildings dominated by spacious courtrooms. ${ }^{275}$ Occasionally, a room is specifically designed for settlement processes. For example, in another recently built federal courthouse in Portland, Oregon, one conference room (to be used for mediation or other such processes) per floor is tucked away behind the courtrooms and not easily accessible to the general public. ${ }^{276}$ In short, although the

\footnotetext{
${ }^{271}$ In the District of Massachusetts, of 3,263 civil filings, 142 completed a trial. Of the 3,105 cases terminated, 84 did so during or after trial, for a rate of about 2.7 percent. See Administrative Office of the U.S. Courts, Judicial Business of the U.S. Courts, Supplemental Tables C2, C4A, and C7 (1998), available at <http://www.uscourts.gov/dirrpt98/index.html>.

${ }^{272}$ This estimate is low because the District of Massachusetts holds court in Springfield and Worcester, as well
as in the new courthouse in Boston. On the other hand, when trials occur, many last longer than did trials
of decades ago. For example, in 1998 , of civil cases tried to completion in the District of Massachusetts,
33 percent took a day; 16 percent two days; 6 percent three days; 35 percent four to nine days; and 9
percent took 10 or more days. See AO Judicial Business 1998 , supra note 241 , tbl, C-8 at 181 . Nationally, 44
percent of civil cases took a day; 16 percent two days; 13 percent three days; 24 percent four to nine days;
and 4 percent more than 10 days. In contrast, in 1984 , 46 percent took a day, 33 percent two to three
days, 19 percent four to nine days, and 3 percent more than 10 days. See Judith Resnik, Failing Faith:
Adjudicatory Procedure in Decline, 53 U. Chi. L. Rev. 494, Appendix A, tbl. 2, Estimated Length of Civil
Trials (1986).
}

${ }^{279}$ See GAO Courthouse Construction 2000, supra note 253. For example, in the more than 3,100 civil cases ended in the District of Massachusetts during the year, judges would have used courtrooms for hearings on contested motions or for other purposes. Further, more than 1,500 criminal defendants appeared during the year.

${ }^{274}$ See D. Mass. R. 16.4(A). See also Local Rule 16(2) (c) District of Connecticut (requiring that participants in settlement conferences come with authority to settle cases). See generally Judith Resnik, Mediating Preferences: Litigants' Preferences for Process and Judicial Preferences for Settlement, 1 Mo. J. Disp. Resol. 155 (2002).

${ }^{275}$ Examples include the U.S. Federal Courthouse in Minneapolis, MN and the Thomas Eagleton Courthouse in St. Louis, MO.

${ }^{276}$ Courthouse tour, Portland, OR, Mar. 15, 1999. 
federal judiciary has been eager-through rules, practices, education, and decisions-to transform the processes of judging, its buildings have not followed suit.

In the United States and elsewhere, courthouses have often been multi-use buildings. ${ }^{277}$ In the federal system, the buildings sometimes provided spaces for customs officials or post offices as well as for courtrooms. ${ }^{278}$ The new Federal Courthouse in Boston emulates this tradition by aspiring to serve as a venue for civic education, including programs teaching children about the justice system. ${ }^{279}$ Moreover, imposing courtrooms may have settlement value as well. When Dennis Curtis and I did a program on art and architecture for judges of the Eighth Circuit, ${ }^{280}$ we noted the lack of facilities designed for settlement discussions. Several district and magistrate judges responded that we had underestimated the utility of courtrooms. We were told that, when seeking to settle cases, judges would bring litigants into large courtrooms-to warn them about the pain of trials and to impress on them the desirability of avoiding trials.

For the federal judiciary to continue to expand and prosper, it depends on Congress - to vest it with jurisdiction and to supply it with buildings, staff, and funds. The justification for budgets to make courthouses secure has, unfortunately, become easy in the wake of fears of terrorism. But under conditions of austerity, congressional support for other funding may well decline. Headlines from the federal judiciary's newsletter make this point ${ }^{281}$ complaining that the Bush Administration in 2003 provided no funds for 26 courthouse construction projects. ${ }^{282}$ The paragraph excerpted above from the AO Report about the many tasks judges do, aside from

\footnotetext{
${ }^{277}$ See Clare Graham, Ordering Law: The Architectural and Social History of the English Law Court to 1914 (Ashgate, 2003) (providing a history of the courthouse developing as a "segregated accommodation" over centuries, as courtrooms moved from inside town halls to take their places in specially designed and singleuse buildings).
}

${ }^{278}$ Lois Craig, Federal Presence: Architecture, Politics and Symbols in United States Government Building (1977).

${ }^{279}$ See Democracy \& Justice: A Newsletter by the James D. St. Claim Court Education Project (Fall/Winter
2003) (describing the project's founding in 1998 under the auspices of the Boston Bar Foundation and now
functioning as a nonprofit organization housed in the U.S. Courthouse in Boston-providing programs for
children about justice and tours of the courthouse). See also General Services Administration, U.S. Court-
house, Boston, Mass., Courts and Community (describing planned programs for outreach to the commu-
nity); Boston Bar Association Alliance (describing the establishment of a Federal Court Public Education
Fund); The Federal Court Public Education Project (sponsored by the Boston Bar Association and the Boston
Bar Foundation, Report, spring 1999) (on file with the author).

${ }^{280}$ Visions of Justice, held at the Eighth Circuit Judicial Conference, Duluth, MN (August 6, 2002).

${ }^{281}$ See, e.g., New Judges, No Room, 35 Third Branch 1 (Aug. 2003); Can the Courts Survive the Coming Austerity?, 35 Third Branch 1 (Oct. 2003).

${ }^{282}$ White House Cuts Courthouses for FY 2004, 35 Third Branch 6 (Feb. 2003). 
trials, suggests that the leadership of the federal judiciary has some sensitivity to the tension between its own staffing and building goals and the decline in the number of trials.

Further, the recent opposition by the Chief Justice to the congressional restrictions on judicial authority over sentencing ${ }^{283}$ (the "Feeney Amendment") ${ }^{284}$ may also be the harbinger of a shift toward judicial protection of the practices of adjudication. As Judge Young has noted, the federal judiciary did not oppose congressional limitations on its jurisdiction over prisoner litigation that were imposed in $1996 .{ }^{285}$ Moreover, in the 1990s, the Chief Justice had objected to judges registering their opposition to mandatory minimums and had urged deference to Congress when sentencing was at issue. ${ }^{286}$ But the 2003 incursions on judicial autonomy in sentencing have prompted the Chief Justice to champion the role of the federal judiciary as an adjudicatory body; he argued that the judge ought to be empowered to decide, based on the record of individual cases, about the time to be served by criminal defendants. ${ }^{287}$ Similarly, the declining trial rates are bringing forth symposia such as this one to puzzle about trends produced through policies championed over the last decades.

The issue remains whether the federal judiciary and members of the elite bars will go further, to use their own infrastructures to do research and to lobby for a judicial system that encompasses all the public providers and regulates the private sector. As the history of the development of data on trial rates demonstrates, leaders of the bench and bar have marshaled the resources and authority to bring attention to segments of adjudication's processes. But the data gathered and the support provided

\footnotetext{
${ }^{289}$ The Chief Justice objected that while Congress had authority over sentencing, targeting "the judicial decisions of individual federal judges could appear to be an unwarranted and ill-considered effort to intimidate judges in the performance of their duties." Sec William Rehnquist, Chief Justice's Year End Report on the Federal Judiciary (2003), available at <http://www.supremecourtus.gov/publicinfo/year-end/2003yearendreport.html> [hereinafter Rehnquist's 2003 Year End Report]. The controversy thereafter involved an exchange of letters, reproduced in Letters to Congress from Sentencing Commissioners, Judicial Conference and Chief Justice Rehnquist, 15 Federal Sentencing Rep. 141 (June 2003).

${ }^{284}$ Child Abduction and Prevention Act (called the "PROTECT Act"), 108th Cong. (2003), Pub. L. No. 108-21, 401 (g), 117 Stat. 650, 671 (2003), codified as amended at scattered sections of Titles 18 and 28 of U.S.C. That amendment requires the U.S. Sentencing Commission to investigate and review departures made by judges. See 18 U.S.C. $\$ 3553$ (West 2004).

${ }^{285}$ See Young, Open Letter to U.S. District Judges, supra note 33, at 33-34 (discussing the Anti-Terrorism and Effective Death Penalty Act (AEDPA), and the Illegal Immigration Reform and Immigrant Responsibility Act of 1996 (IIRIRA)).

${ }^{286}$ William H. Rehnquist, Chief Justice Rehnquist Reflects on 1994 in Year-End Report, 27 Third Branch 1, 3 (1995).

${ }^{287}$ Rehnquist's 2003 Year End Report, supra note 283. See also Judicial Conference Seeks Restoration of Judges' Sentencing Authority, 35 Third Branch 2 (Oct. 2003).
} 
do not map most of the instances when disputants come to state and federal courts and agencies in search of law's decisions. My claim is not that the leadership has ignored the panoply; both judges and lawyers have argued many times for protection of processes and resources for court-based and for administrative adjudication. ${ }^{288}$ But the allocation of attention and resources flowing to one relatively small sector of the system has far outstripped those devoted to the volume in other sectors.

Above, I offered two conflicting but plausible readings of the data on "The Vanishing Trial." What those data also demonstrate is that institutions built during the 20th century have the potential to make profound changes in the opportunities for disputants to use the law and to learn about how others use the law. The data have taught us that information can, with effort and ingenuity, be produced. The choice, then, belongs to us as to which of the competing theses-the migration and proliferation of trials supported by public resources and laws or the privatization and devaluation of trials, also supported through public policies-will turn out to be "true."

\footnotetext{
${ }^{288}$ See, e.g., letter of Oct. 9, 2002 from Alfred P. Carlton, as President of the ABA to the Hon. Jo Anne B. Barnhart, Commissioner of Social Security Administration (expressing concern about the proposals that would "jeopardize due process protections of Social Security disability" beneficiaries by objecting to the plan to substitute non-APA hearing officers for ALJs).
} 
HeinOnline -- 1 J. Empirical Legal Stud. 8422004 